\title{
Extracellular vesicle cross-talk in the bone marrow microenvironment: implications in multiple myeloma
}

\author{
Jinheng Wang ${ }^{1, *}$, Sylvia Faict ${ }^{1, *}{ }^{*}$ Ken Maes ${ }^{1}$, Elke De Bruyne ${ }^{1}$, Els Van Valckenborgh ${ }^{1}$, \\ Rik Schots ${ }^{2}$, Karin Vanderkerken ${ }^{1, *}$ and Eline Menu ${ }^{1, *}$ \\ ${ }^{1}$ Department of Hematology and Immunology, Myeloma Center Brussels, Vrije Universiteit Brussels (VUB), Brussels, Belgium \\ 2 Department of Clinical Hematology, Universitair Ziekenhuis Brussel, Brussels, Belgium \\ * These authors have contributed equally to this work
}

Correspondence to: Eline Menu, email: Eline.Menu@vub.ac.be

Keywords: extracellular vesicle; exosome; multiple myeloma; bone marrow microenvironment; cross-talk

Received: December 21,2015 Accepted: February 21,2016 Published: February 29, 2016

\section{ABSTRACT}

The bone marrow (BM) represents a complex microenvironment containing stromal cells, immune cells, osteoclasts, osteoblasts, and hematopoietic cells, which are crucial for the immune response, bone formation, and hematopoiesis. Apart from soluble factors and direct cell-cell contact, extracellular vesicles (EVs), including exosomes, were recently identified as a third mediator for cell communication. Solid evidence has already demonstrated the involvement of various BM-derived cells and soluble factors in the regulation of multiple biological processes whereas the EVmediated message delivery system from the BM has just been explored in recent decades. These EVs not only perform physiological functions but can also play a role in cancer development, including in Multiple Myeloma (MM) which is a plasma cell malignancy predominantly localized in the BM. This review will therefore focus on the multiple functions of EVs derived from BM cells, the manipulation of the BM by cancer-derived EVs, and the role of BM EVs in MM progression.

\section{INTRODUCTION}

The bone marrow (BM) is the source of blood cells and immune cells, and contains a complex environment composed of a cellular compartment, an extracellular matrix, and a liquid compartment [1]. The communication between BM-derived cells, mainly mediated by direct cell-to-cell contact, soluble molecules, and extracellular vesicles (EVs), maintains the physiological functions of the BM. Direct contact involves the interaction of a set of receptors and ligands on the cell membrane, leading to signal transduction and phenotypic changes in BMderived cells, followed by the release of intercellular molecules $[2,3]$. Soluble molecules, such as growth factors, cytokines, and chemokines, released from cells bind to the cognate receptors on the surface of target cells, leading to the activation or suppression of intracellular signaling pathways. EVs, a class of membranous vesicles, are secreted by various cell types into the extracellular microenvironment and mediate short- and long-range communication by stimulating target cells with receptors or ligands, transferring membrane receptors to target cells, delivering functional intracellular molecules, and inducing epigenetic changes in recipient cells $[4,5]$.

Based on the origin of the membrane, EVs can be classified into two primary types, termed exosomes and shedding vesicles [6]. Exosomes are nanometric membrane vesicles derived from late endosomes [7] and released through the fusion of multivesicular bodies (MVBs) with the plasma membrane [6, 8]. The formation of these exosomes starts in early endosomes, which are generated by invagination and endocytosis of the plasma membrane and its receptors. Intraluminal vesicles (ILVs) are generated inside the endosomes by inwards budding, and the early endosomes are then termed MVBs [9]. MVBs can either fuse with lysosomes or the trans-Golgi network, resulting in the degradation or recycling of the ILVs, or they can fuse with the plasma membrane, in which case the ILVs are released as exosomes [10]. Two major mechanisms are important in the formation and release of exosomes: the Endosomal Sorting Complex Required for Transport (ESCRT)-dependent mechanisms and the ESCRT-independent mechanisms [11]. The ESCRT exists of four different complexes, each involved in different steps of the formation of MVBs and the exosome release process [12]. Some of the 
ESCRT complexes used in the assembly and secretion of exosomes, such as ESCRT-III, are also important in the release of shedding vesicles [13]. Additionally, accessory proteins such as Alix, which is associated with ESCRT-III and promotes the intraluminal budding of vesicles inside the endosomes, are necessary for optimal biogenesis of exosomes [14]. Mechanisms independent from this ESCRT-complex involve lipids, tetraspanins or heat shock proteins. Ceramide has been shown to play an important role in exosome formation, loading and secretion, and inhibition of neutral sphingomyelinase can impair the secretion of exosomes $[15,16]$. Shedding vesicles generally referred to as microparticles, ectosomes, microvesicles (MVs), exovesicles, and apoptotic blebs are secreted by direct budding or shedding from the plasma membrane [17]. Exosomes and shedding vesicles both contain enzymes, nucleic acids, transcription factors and proteins, and are enriched in certain lipid contents (sphingomyelin, cholesterol, glycerophospholipid and ceramide) [18]. Based on the EV types, different methods, including differential centrifugation, density gradient centrifugation, size exclusion chromatography, immune magnetic sorting or precipitation using easyto-use precipitation solutions (eg. ExoQuick and Total Exosome Isolation) are commonly used. Due to the similar characteristics between some EV types (eg. microparticles and MVs) and the lack of standardized methods, the EV purity used in most of these studies is quite different, not unified and short of quality controls. Therefore there is an urgent need to establish standardized protocols to be able to interpret functional data correctly. Nevertheless, numerous functional studies have already been performed and will be discussed here.

In recent years, the close association of EVs with the immune response $[3,19]$, antigen presentation [17], tumor cell survival [20], cell migration [2123], tumor cell invasion [24], cell differentiation [25], and angiogenesis [21, 23] has been demonstrated. As communicators, EVs are also involved in the regulation of the BM microenvironment and the communication between BM-derived cells and cells from other tissues. Recent evidence shows that tumor cells, such as breast cancer cells, melanoma cells, prostate cancer cells, and cholangiocarcinoma cells, from outside the BM can disturb the balance of the BM microenvironment and educate the BM-derived cells toward a pro-angiogenic and pro-metastatic phenotype through EV-mediated long-range communication [26-29]. Education of the BM microenvironment by tumor-derived EVs further support tumor growth, vasculogenesis, invasion, metastasis, and immune evasion. Thus, in this review we will provide a comprehensive overview of the biological functions of EVs, in particular exosomes, derived from normal or cancer cells in the BM microenvironment with a specific emphasis on the role in multiple myeloma (MM), a malignancy localized in the BM.

\section{BM CELL-DERIVED EVS}

The cellular BM compartment consists of the hematopoietic cells which contain the intermediates of hematopoiesis and thrombopoiesis, plasma cells, and myeloid and lymphoid precursor cells, and the BM stroma, including adipocytes, BM stromal cells (BMSCs), mesenchymal stromal cells (MSC), osteoblasts, osteoclasts and endothelial cells. The EVs derived from the intermediates or precursor cells of hematopoiesis have not been investigated due to the instability of these not fully differentiated populations. Thus, studies mainly focused on the functions of EVs derived from BM stroma cells and fully differentiated hematopoietic cells and showed that each of these cell types produces EVs which affect homeostasis of the BM microenvironment and biological processes outside of the BM.

\section{MSC-derived exosomes}

MSCs are multipotent stromal cells that are able to differentiate into a variety of cell types including osteoblasts, chondrocytes, myocytes, and adipocytes [30]. As a carrier of various cargo, the content in MSCderived EVs has been investigated. Baglio et al. have demonstrated that BM MSC-derived exosomes are highly enriched in tRNAs, representing $>35 \%$ of total small RNAs, while mature microRNAs (miRNA) account for only $2-5 \%$, which differ from those in tissue specific MSC-derived exosomes [31]. In addition, a select pattern of miRNA important for metabolic processes, proliferation, differentiation and homing of stem cells are present in BM MSC-derived EVs [32]. Tomasoni et al. have demonstrated that BM MSC-derived exosomes horizontally transferred insulin-like growth factor-1 receptor (IGF-1R) mRNA to proximal tubular epithelial cells and increased their proliferation [33]. By using small RNA sequencing, proteomic, lipidomic, and metabolite assays, Vallabhaneni et al. have recently determined the total cargo of EVs derived from MSCs, and found several well-identified tumor supportive miRNAs (miRNA-21 and -34a) and proteins (PDGFR- $\beta$, TIMP-1, and TIMP-2), bioactive lipids (sphingomyelin and diacyl-glycerol), and metabolites (glutamic and lactic acid) [34].

Multiple functions of BM MSC-derived EVs have been revealed in normal biological processes and cancer progression. First, MSCs can modulate the immune system. Although this is largely mediated by paracrine factors, EVs secreted from these cells have also been reported to contribute to the regulation of the immune system. In a study by Favaro et al., BM MSC-derived EVs could be internalized by PBMCs (peripheral blood mononuclear cells) obtained from patients with a recent diagnosis of diabetes type I and suppressed their response to stimulation by suppressing the Th1 and Th17 response, 
upregulating regulatory $\mathrm{T}$ cells, and increasing IL-10, TGF- $\beta$ and PGE2 [35]. In a different study, EVs could suppress the $\mathrm{T}$ cell response by inducing apoptosis of $\mathrm{CD}^{+}$and $\mathrm{CD}^{+}$cells in PBMCs (rather than inhibiting their proliferation) and by stimulating proliferation of regulatory $\mathrm{T}$ cells, leading to increased IL-10 [36]. In a study to reduce GvHD (graft versus host disease), MSCderived exosomes were found to decrease the release of IL1- $\beta$, TNF- $\alpha$, and IFN- $\gamma$ from PBMCs and the secretion of TNF- $\alpha$ and IFN- $\gamma$ from natural killer (NK) cells, further confirming their immunosuppressive activities [37]. Apart from immune effects, proangiogenic roles of MSC-derived EVs have been demonstrated as they can be taken up by endothelial cells and induce their proliferation, migration and tube formation [38, 39].

Effects of EVs derived from BM MSCs on cancer progression have also been studied in various cancer types. Ono et al. have demonstrated that MSC-derived exosomes promoted breast cancer cell dormancy in a metastatic niche by the transfer of miR-23b, and inhibited the proliferation and invasion of cancer cells [40]. An earlier study by Lim et al. has similarly determined that BMSCderived exosomes favor breast cancer dormancy through transfer of miRNAs targeting CXCL12 and reducing cell proliferation [41]. Co-injection of MSC-derived exosomes with gastric carcinoma cells led to the promotion of both tumor incidence and growth in vivo [42]. MSC-derived EVs also favor the growth of breast cancer cells in vivo, indicating their tumor supportive function [34]. In contrast, Bruno et al. have found that EVs derived from MSCs inhibited the proliferation of three different tumor cell lines in vitro and in vivo, and these tumor cells tend to go into apoptosis or necrosis after treatment with EVs [43]. In view of the contrasting results in either tumor induction or suppression by MSCs and their EVs, it seems that the timing of injection is critical. EVs from MSCs coinjected with tumor cells seem to promote tumor growth, whereas they suppress tumor progression when they were administered after the tumor had been established [43]. Additionally, the source of the obtained MSCs seems to be of capital importance as shown by Del Fattore et al., who demonstrated that EVs from MSCs derived from either BM or the umbilical cord decreased proliferation and induced apoptosis of glioblastoma cells in vitro, while EVs from MSCs isolated from adipose tissue had opposite effects [44].

\section{Dendritic cell (DC)-derived EVs}

DCs are antigen presenting cells originating from the myeloid lineage in the bone marrow and can exist in either a mature or immature stage. Immature DCs specialize in antigen capture, but cannot present them efficiently to $\mathrm{T}$ cells. They frequently induce immune tolerance in T cells due to low expression of MHC class I and class II, as well as costimulatory molecules such as CD80 and CD86. Activated mature DCs are among the most potent antigen presenting cells for activating $\mathrm{T}$ cells and carry higher levels of $\mathrm{MHC}$ and costimulatory molecules on their surface. Subsequently, these mature DCs efficiently induce the activation of the immune response upon stimulation [45]. Immature and mature DCs play important roles in initiating and shaping both the innate and adaptive immune responses, thereby regulating immune microenvironments in the BM or tumor [46].

Exosomes derived from DCs, also called dexosomes, have recently gained much attention in tumor vaccination studies as they express functional MHC class $\mathrm{I}$ and II and T cell co-stimulatory molecules which are essential for activating immunologic effector cells [4750]. Exosomes secreted from mouse DCs were shown to induce antitumor effects through activating $\mathrm{CD}^{+}, \mathrm{CD}^{+}$ $\mathrm{T}$ cells, and invariant NKT cells $[48,51,52]$. Dexosomes loaded with antigenic protein or peptide, or exosomes derived from antigen-pulsed DCs promoted transgenic $\mathrm{T}$ cell proliferation in vitro, whereas only protein-loaded dexosomes induced $\mathrm{T}$ cell response and Th1-type memory in vivo in a B cell-dependent manner [53]. Protein-loaded dexosomes inhibited tumor growth in mice by inducing antitumor immunity in the assistance of proper activation of both $\mathrm{CD}^{+} \mathrm{T}$ and $\mathrm{B}$ cells [54]. Both murine and human dexosomes promoted NK cell proliferation and activation in vivo in an IL-15R $\alpha$ - and NKG2D-dependent manner, resulting in tumor regression [49].

Because dexosomes reflect the phenotype of the parental DC at the time of isolation, dexosomes derived from mature DCs activate $\mathrm{T}$ cells more efficiently than those derived from immature DCs [55]. Indeed, dexosomes derived from immature DCs (imDex) have more immunosuppressive properties. They can suppress the development of myasthenia gravis in mice, by lowering both the proliferation of lymphocytes and production of antibodies. Lymphocytes from these treated mice exhibited lower expression of immune response factors such as IFN $\gamma, \mathrm{TNF} \alpha$ and IL-6 [56]. Additionally, donor-derived imDex helped to induce immune tolerance in murine allograft models by inhibiting $\mathrm{T}$ cell activation, resulting in less rejection and longer survival of recipient mice [57-60]. Also, in sepsis, imDex containing milk fat globule epidermal growth factor-VIII (MFG-E8) enhanced macrophages-mediated phagocytosis of apoptotic cells and therefore decreased the inflammatory response [61, 62].

Some researchers have investigated whether changes in DCs can influence the dexosomes. Exosomes derived from DCs treated with IL-10 had immunosuppressive effects and could modulate the $\mathrm{T}$ cell response in an antigen specific and MHC class II dependent way [63, 64]. Exosomes from genetically modified DCs expressing Fas ligand (FasL), IL-4 or indoleamine 2,3-dioxygenase (IDO) were anti-inflammatory and immunosuppressive [65-67].

We can conclude that dexosomes can have conflicting functions, and it seems that the regulation of 
Table 1: The functions of EVs derived from BM cells

\begin{tabular}{|c|c|c|c|c|}
\hline Source cell & Type of EVs & Target cell & Functions & Ref. \\
\hline MSC & EVs & Treg, $\mathrm{CD}^{+}$cell & $\begin{array}{l}\text { Promote proliferation and apoptosis of Treg; } \\
\text { induce } \mathrm{CD}^{+} \text {cell apoptosis }\end{array}$ & 36 \\
\hline MSC & Exosomes & Immune cell & Induce immunosuppression & 37 \\
\hline MSC & Microvesicles & PBMC & Decrease Th17 cells and increase Treg & 35 \\
\hline MSC & $\begin{array}{l}\text { Microparticles } \\
\text { and exosomes }\end{array}$ & $\begin{array}{l}\text { Proximal tubular } \\
\text { epithelial cell }\end{array}$ & Promote cell proliferation & 33 \\
\hline $\mathrm{MSC}$ & EVs & Endothelial cell & Promote tube formation and proliferation & 38 \\
\hline MSC & 40-150nm EVs & Breast cancer cell & Promote tumor growth in vivo & 34 \\
\hline BMSC & Exosomes & Breast cancer cell & Reduce CXCL12 and decreased proliferation & 41 \\
\hline MSC & Exosomes & Gastric cancer cells & Promote tumor growth in vivo & 42 \\
\hline MSC & Microvesicles & $\begin{array}{l}\text { Hepatoma, Kaposi's sarcoma, } \\
\text { and ovarian tumor cell lines }\end{array}$ & $\begin{array}{l}\text { Inhibit cell cycle progression; induce apoptosis; } \\
\text { inhibit tumor growth in vivo }\end{array}$ & 43 \\
\hline MSC & EVs & Glioblastoma cell line & Decrease cell proliferation, induced apoptosis & 44 \\
\hline $\begin{array}{l}\text { peptide-pulsed } \\
\text { DC }\end{array}$ & Exosomes & $\mathrm{T}$ cell & $\begin{array}{l}\text { Induce specific cytotoxic T lymphocytes in vivo } \\
\text { and suppress tumor growth }\end{array}$ & 48 \\
\hline $\mathrm{DC}$ & Exosomes & NK cell & $\begin{array}{l}\text { Induce NK cell proliferation and activation in } \\
\text { vivo }\end{array}$ & 49 \\
\hline imDC & Exosomes & NK cell & NK cell activation & 50 \\
\hline $\mathrm{DC}$ & Exosomes & $\mathrm{CD}^{+} \mathrm{T}$ cell & T cell activation & 51 \\
\hline $\mathrm{DC}$ & Exosomes & iNKT cell & $\begin{array}{l}\text { Activate iNKT cells and induce } \\
\text { cancer-specific adaptive immune response }\end{array}$ & 52 \\
\hline $\mathrm{DC}$ & $\begin{array}{l}\text { Antigen-loaded } \\
\text { exosomes }\end{array}$ & $\mathrm{T}$ cell & $\begin{array}{l}\text { Induce specific transgenic } \mathrm{T} \text { cell proliferation } \\
\text { and response; Th1-type shift }\end{array}$ & 53 \\
\hline $\mathrm{DC}$ & $\begin{array}{l}\text { Antigen-loaded } \\
\text { exosomes }\end{array}$ & $\mathrm{CD}^{+} \mathrm{T}$ cell & Induce cytotoxic $\mathrm{T}$ cell response & 54 \\
\hline imDC & Exosomes & Lymphocyte & Reduce proliferation & 56 \\
\hline $\operatorname{imDC}$ & Exosomes & $\mathrm{T}$ cell & $\begin{array}{l}\text { Suppress T cell response and increase } \\
\text { IL-10 production }\end{array}$ & 57 \\
\hline $\operatorname{imDC}$ & Exosomes & $\mathrm{T}$ cell & Immunosuppression & 58 \\
\hline $\mathrm{DC}$ & Exosomes & $\mathrm{T}$ cell & Reduce $\mathrm{T}$ cell responses & 59 \\
\hline imDC & Exosomes & $\mathrm{T}$ cell & Stimulate $\mathrm{CD}^{+} \mathrm{T}$ cells & 61 \\
\hline $\begin{array}{l}\text { imDC treated } \\
\text { with IL-10 }\end{array}$ & Exosomes & N/A & \begin{tabular}{|lll}
$\begin{array}{l}\text { Suppress inflammation and autoimmune } \\
\text { responses }\end{array}$ & and \\
\end{tabular} & 63 \\
\hline $\begin{array}{l}\text { DC over- } \\
\text { expressing FasL }\end{array}$ & Exosomes & N/A & $\begin{array}{l}\text { Induce antigen-specific immune responses in } \\
\text { vivo }\end{array}$ & 65 \\
\hline $\begin{array}{lr}\text { DC } & \text { over- } \\
\text { expressing IL-4 }\end{array}$ & Exosomes & DC, macrophage, $T$ cell & Suppress inflammatory response & 66 \\
\hline $\begin{array}{l}\text { Infected } \\
\text { macrophages }\end{array}$ & $50-300 \mathrm{~nm} \mathrm{EVs}$ & Naive macrophage & Induce pro-inflammatory cytokines production & 70 \\
\hline $\begin{array}{l}\text { Infected } \\
\text { macrophages }\end{array}$ & Exosomes & $\mathrm{DC}, \mathrm{T}$ cell & $\begin{array}{l}\text { Stimulate activation and maturation of } \mathrm{DC} \text {; } \\
\text { activate antigen-specific } \mathrm{CD} 4^{+} \text {and } \mathrm{CD} 8^{+} \mathrm{T} \text { cells }\end{array}$ & 71 \\
\hline $\begin{array}{l}\text { Infected } \\
\text { macrophages }\end{array}$ & Exosomes & Naive macrophage & Recruit and activate macrophage & 72 \\
\hline $\begin{array}{l}\text { Infected } \\
\text { macrophage }\end{array}$ & Exosomes & Naive macrophage & $\begin{array}{l}\text { Suppress IFN- } \gamma \text { mediated activation of } \\
\text { naive macrophages }\end{array}$ & 73 \\
\hline Mast cells & Exosomes & Spleen cell & 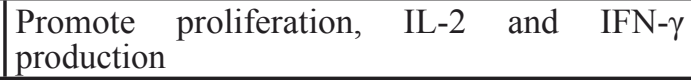 & $\begin{array}{l}74 \\
75\end{array}$ \\
\hline Adipocytes & Exosomes & Osteoblast & $\begin{array}{l}\text { Induce the expression of adipocyte specific } \\
\text { genes }\end{array}$ & 76 \\
\hline
\end{tabular}

EV, extracellular vesicle, MSC, mesenchymal stromal cells; Treg, regulatory T cells; BMSC, bone marrow stromal cells; DC, dendritic cells; iNKT cell: invariant natural killer T cell. 
immune activation and tolerance mediated by dexosomes depends on the maturation stage of the originating DCs, the microenvironment where the exosome-DC interaction takes place, as well as the stimulation of DCs $[68,69]$.

\section{Other BM cell-derived EVs}

Macrophages are derived from the monocyte lineage in the BM. EVs released from infected macrophages induced immune activation by activation of other naive macrophages, maturation of DCs, and activation of $\mathrm{CD}^{+}$ and $\mathrm{CD}^{+} \mathrm{T}$ cells [70-72]. An earlier study by Singh et al. however indicated that exosomes from infected macrophages could transfer IFN- $\gamma$ unresponsiveness to naive, uninfected macrophages and inhibit their activation [73]. Mast cells, derived from myeloid stem cells, secreted immunologically active exosomes which could induce $\mathrm{B}$ and $\mathrm{T}$ cell proliferation and promote the production of IL-2 and IFN- $\gamma$ both in vitro and in vivo. These exosomes expressed multiple immunologically relevant molecules, such as MHC Class II, CD86, CD40, CD40L, LFA-1, ICAM-1, and CDC25 [74, 75]. Valadi et al. demonstrated that mast cell-derived exosomes contain various small RNAs including functional mRNAs and miRNAs and thus mediate the genetic exchange between cells [18]. In a model of osteoporosis, it was shown that EVs released from BM MSC-derived adipocytes could transfer adipogenic RNA to osteoblasts, resulting in the expression of adipocyte specific genes by osteoblasts, which ultimately led to increased marrow adiposity and bone loss [76].

EVs secreted by the cells in the BM are involved in various processes through affecting immune response, cell differentiation, angiogenesis, and cancer progression, as summarized in Table 1. However, as stated above, contradictory results frequently occur, which may be caused by the inconformity of target cell types, EV types, or the mouse model used in these studies. The establishment of unified investigation on the functions of EVs derived from the BM cells is needed to better understand the EV-mediated communications.

\section{EFFECT OF TUMOR-DERIVED EVS ON BM-DERIVED CELLS}

Intercellular communication between cancer and normal cells in the tumor microenvironment plays a pivotal role in the development and progression of cancer. The various roles of tumor-derived EVs, especially exosomes, in the local communication and cancer progression within the tumor microenvironment have been well studied and discussed in recent years [77-79]. Allopatry of solid tumor cells and the BM makes direct contact impossible, whereas soluble factors and EVs can bridge the gap and facilitate long-range communication. Indeed, tumor- derived soluble factors promote the mobilization and accumulation of BM-derived cells, including endothelial progenitor cells, MSCs, and myeloid-derived suppressor cells (MDSCs), out of the BM into the circulation and tumor microenvironment [80-85]. Numerous studies have also shown that tumor-derived EVs may target BM-derived cells to modify the BM microenvironment which in turn supports the growth of tumor cells through modulating angiogenesis, tumor cell migration, immune response, drug resistance and metastasis.

It has been shown that microparticles from paclitaxel treated breast carcinoma cells contain osteopontin by which they induce BM-derived proangiogenic cell mobilization and colonization, leading to microvessel sprouting and increased angiogenesis, which ultimately accelerates tumor growth [86]. In a different study, the anti-VEGF-A antibody B20 reduced the level of VEGF-A enclosed in breast cancer cell-secreted microparticles and these vesicles were unable to activate endothelial cells and could not promote BM-derived proangiogenic cell colonization [87]. In addition, exosomes derived from hematological tumor cells such as chronic myelogenous leukemia cells and MM cells also contribute to angiogenesis [88-91]. Umezu et al. have reported that leukemia cell-derived exosomes transfer miR-92a to vein endothelial cells and enhance their migration and tube formation without affecting their growth [89]. Hypoxia, an important element in the cancer microenvironment, modulates the release and miRNA profile of exosomes from leukemia or myeloma cells, which finally leads to an enhancement of angiogenesis $[88,90]$.

Over the entire process of cancer development, cancer cells interact intimately with the immune system to favor immune evasion. Evasion of the immune response involves three major mechanisms: the selection of tumor variants resistant to immune effectors, immuneresistant changes in tumor cells, and formation of an immunosuppressive microenvironment [92]. The latter involves attracting immune suppressive cells from the BM through soluble factors or EVs. The most prominent of these immune suppressive cells is the MDSC. This cell type of myeloid origin interferes with $\mathrm{T}$ cell responses in a variety of pathologies, including cancer. It was demonstrated that tumor-derived exosomes could be taken up by BM MDSCs in vivo and these exosome-activated MDSCs not only suppressed T cell activation, they also enhanced tumor growth [93, 94]. In addition, tumorderived exosomes can increase cytokine production by the MDSCs [28]. From a mechanistic point of view it has been reported that the STAT3-dependent immunosuppressive activity of mouse and human MDSCs is induced by membrane-associated Hsp70 on tumor-derived exosomes [95]. These findings emphasize the involvement of tumorderived exosomes in immunosuppression, leading to an acceleration of tumor progression.

Tumor-derived EVs are also involved in the 
induction of various immunomodulatory effects through impacting BM-derived cells. Mammary carcinoma cellderived EVs were found to contribute to the enhancement of the innate inflammatory response mediated by macrophages [96] while melanoma cell-derived exosomes could activate macrophages through the NF- $\kappa \mathrm{B}$ pathway and alter their cytokine/chemokine profile [97]. In addition, these exosomes promoted the maturation of DCs, leading to an enhanced T cell proliferation [97]. In contrast, Yu et al. have shown that mammary tumor cellderived exosomes inhibited differentiation of BM DCs and monocytes [94]. Finally, body fluid exosomes obtained from ovarian cancer patients could enhance the secretion of inflammatory factors, such as IL- $1 \beta$, TNF- $\alpha$, and IL6 , in monocytic cells through toll-like receptor signaling [98].

In recent years, it has been found that EVs can mediate the crosstalk between malignant cells and BMSCs or MSCs. One study reported that BMSCs pulsed with hepatocellular carcinoma-derived exosomes had higher migratory capacities and strong antitumor activities [99]. However by contrast, Corrado et al. have

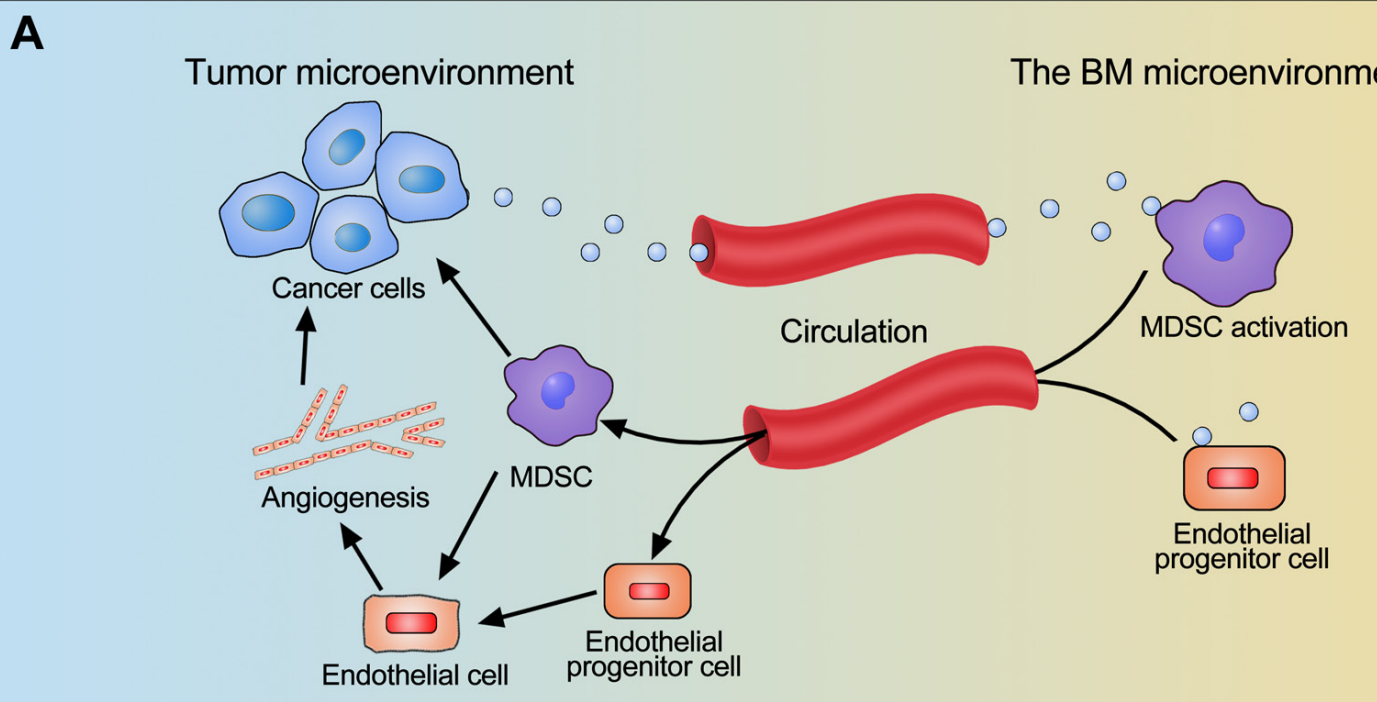

B

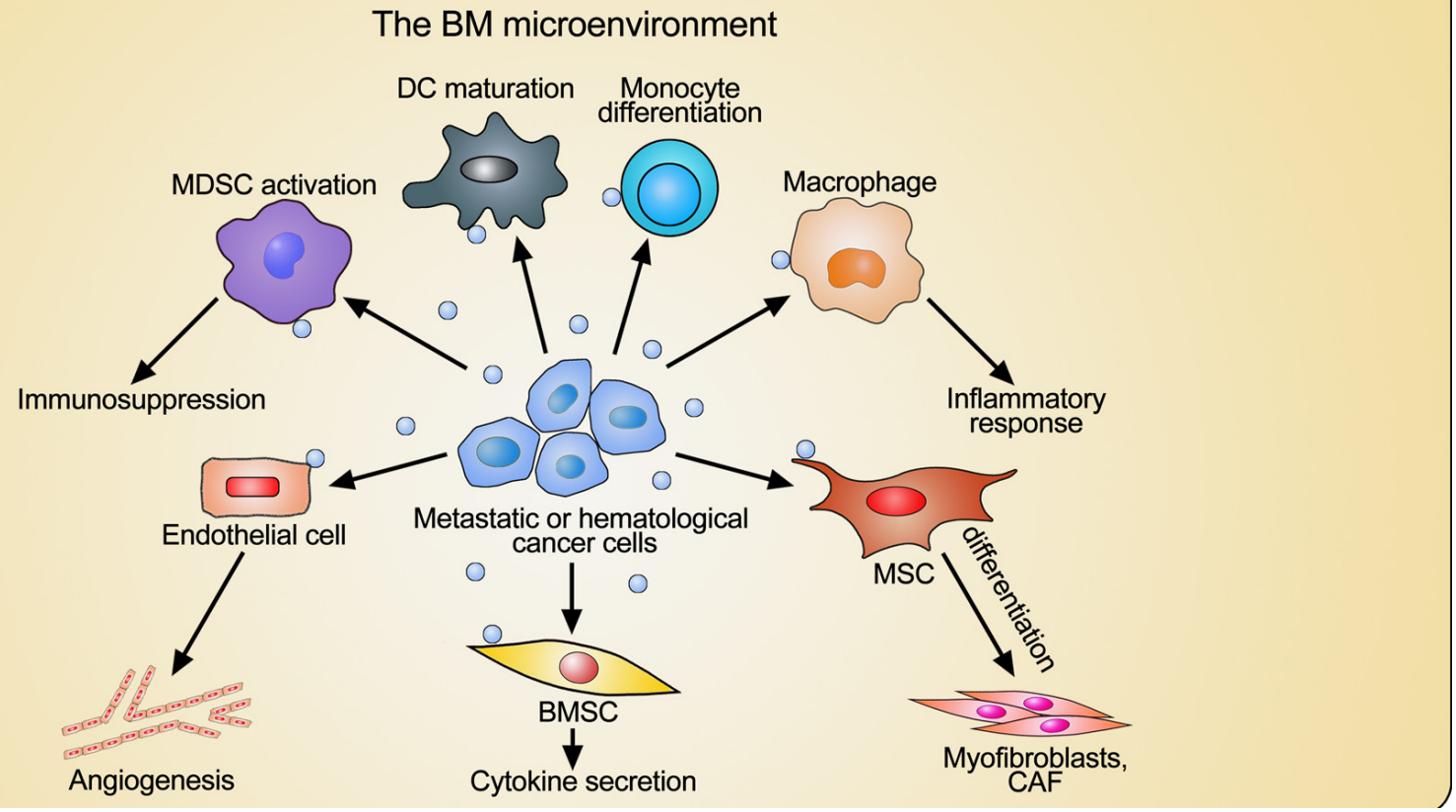

Figure 1: Interaction between cancer cells and BM-derived cells through extracellular vesicles (EVs). A. EVs derived from cancer cells outside of the BM induce the mobilization and localization of MDSCs and endothelial progenitor cells from the BM into the tumor microenvironment and therefore enhance angiogenesis and immunosuppression. B. EVs derived from metastatic or hematological cancer cells induce cell differentiation and maturation, inflammatory response, cytokine secretion, angiogenesis, and immunosuppression in the BM microenvironment through affecting BM-derived cells, including monocytes, dendritic cells (DCs), macrophages, mesenchymal stromal cells (MSCs), BM stromal cells (BMSCs), endothelial cells, and myeloid-derived suppressor cells (MDSCs). This educated BM microenvironment facilitates cancer cell growth. 
shown protumoral effects of BMSCs treated with chronic myelogenous leukemia cell-derived exosomes as these BMSCs secreted more IL-8, promoting leukemia cell growth in vitro and in vivo [100]. In a different report, prostate cancer cell-derived exosomes could trigger MSC differentiation into myofibroblasts which ultimately promoted angiogenesis, tumor cell proliferation and invasion [101]. Similarly, Haga et al. have demonstrated that human cholangiocarcinoma cell-derived EVs induced fibroblastic differentiation in MSCs and these MSCs in turn facilitated tumor cell proliferation and migration [102]. Exosomes released by chronic lymphocytic leukemia cells induced a phenotype of cancer-associated fibroblasts in MSCs and these stromal cells showed enhanced proliferation, migration and secretion of cytokines, which could further favor tumor cell growth [103]. Furthermore, melanoma exosomes educated BM progenitor cells through the receptor tyrosine kinase MET and reprogrammed them towards a pro-angiogenic and pro-metastatic phenotype, which could support tumor growth and metastasis [26]. The complex communication between cancer cells and BM-derived cells through EVs is illustrated in Figure 1.

\section{EVS IN MM}

MM is an often incurable plasma cell neoplasm, which accounts for about $10 \%$ of all hematological cancers and is therefore the second most common hematological malignancy [104, 105]. Malignant plasma cells home to and are predominantly localized in the BM, since this microenvironment is crucial for $\mathrm{MM}$ pathogenesis and progression. Homeostasis of the BM microenvironment is disrupted and modified by the presence of the MM cells, leading to angiogenesis, osteolysis, immune suppression and anemia. Recent research has demonstrated that EVs should also be considered as one of the mediators by which MM cells induce BM microenvironmental modifications, as well as the involvement of EVs in MM development and induction of drug resistance, which will be discussed below.

\section{EV as a biomarker in MM}

Elevated levels of total EVs in the body fluids are found in cancer patients as compared to healthy donors and they are reported to be correlated with cancer stages [106, 107]. In MM, it has been shown that serum samples from $72 \mathrm{MM}$ patients with immunoglobulin light chain amyloidosis contained a higher level of MVs and exosomes than healthy donors [108]. Caivano et al. have recently studied serum EVs in patients with various types of hematological neoplastic disorders and demonstrated similarly that the concentration of serum EVs is significantly elevated in MM patients [109].
In addition, higher level of serum EVs expressing the ectoenzyme CD38 [110], a marker of plasma cells and an often used MM-related antigen was found, implicating that these vesicles originate from MM cells [109]. Similarly, Benameur et al. have found an increase of the total circulating and BM-derived microparticle (MP) number in a mouse model at end stages of MM compared to controls. Phenotypic characterization showed that circulating MPs originated from platelets, leukocytes, endothelial cells, and erythrocytes, while the BM-derived MPs express CD138, another marker for plasma cells [111]. The amount of serum EVs in MM patients has been evaluated by Di Noto et al. through the measurement of their acetylcholinesterase activity. The highest EV amount was found in MM patients in contrast to healthy donors and patients with monoclonal gammopathy of undetermined significance (MGUS) [112]. Moreover, exosome secretion from MM cells was shown to be dramatically increased by heparanase whose expression is up-regulated in aggressive cancer cells including MM cells, implying that heparanase may be one of the factors causing elevated secretion of exosomes [113].

A recent study identified 158 differentially expressed circulating exosomal miRNAs, including let-7 family members, miR-17/92 and miR-99b/125a clusters, in MM compared to normal healthy controls and demonstrated that the circulating exosomal miRNA signature was an independent prognostic marker in MM [114]. Moreover, some of these miRNA correspond to those previously identified as differentially expressed between MM cells and normal PCs [115]. Another similar study demonstrated that specific exosomal miRNAs are differentially expressed between high and low-risk MM patient, further suggesting the potential of exosomal miRNA signatures as a prognostic marker [116]. All these findings suggest that both total serum and tumor antigen-specific EVs including exosomes may represent a novel biomarker in MM and can be used for MM prognosis; however, more studies containing a large number of clinic samples are still needed to further confirm the correlation between EVs and MM progression.

\section{Characterization of MM cell-derived EVs}

The proteomic content of EVs derived from two human MM cell lines has been analyzed by Harshman et al. [117] and they identified 583 vesicular proteins from these vesicles, including antigen presenting molecules, adhesion molecules, membrane transport and fusion molecules, cytoskeletal proteins, pyruvate kinase, histones, and other bioactive proteins involved in multiple biological processes [117]. Enriched membrane molecules such as CD44, MHC class I, and bone marrow stromal antigen 2 (BST-2) were observed in MM cell-derived MVs as compared to MM cells [117]. Elevated expression of CD147 was also found in human MM cell line-derived 
MVs, as well as in MVs from MM BM plasma. Ig light chain-positive MVs from MM patients express higher levels of CD38, CD319, CD44, and CD9 than those from MGUS patients [118]. Moreover, it has been shown that above $80 \%$ of MVs derived from a human MM cell line express CD138 [119].

\section{Function of MM cell-derived EVs}

MM cell-derived EVs have been shown to alter different processes in the BM, such as angiogenesis and osteolysis, to enhance MM growth. Angiogenesis is essential for tumor growth, invasion and metastasis as tumor cells require more nutrients and oxygen from blood vessels. In MM patients, increased angiogenesis has been demonstrated in the $\mathrm{BM}$ and this higher microvessel density is associated with poor prognosis [120-122]. Enhancement of angiogenesis is mainly mediated by the well-known pro-angiogenic factors such as vascular endothelial growth factor (VEGF), basic fibroblast growth factor (bFGF), and angiopoietin-1 secreted by the MM cells or stromal cells interacting with MM cells [123-128]. Two recent studies have demonstrated MVs or exosomes derived from MM cells as new inducers of angiogenesis [88, 119]. MVs secreted from a human MM cell line directly promoted the proliferation and capillary structure formation of umbilical vein cells, and induced angiogenesis in vivo. These EVs promoted the expression and secretion of VEGF in umbilical vein cells, which can further enhance angiogenesis [119]. Hypoxia-inducible factor (HIF)-1 $\alpha$ is often overexpressed by MM cells due to the hypoxic BM environment, leading to increased secretion of proangiogenic cytokines [129, 130]. Umezu et al [88] found that MM cells under hypoxic conditions secreted more exosomes with increased levels of miR$135 \mathrm{~b}$ which induced increased expression of HIF-1 $\alpha$ in endothelial cells, leading to enhanced angiogenesis. Moreover, serum EVs obtained from MM patients clearly promoted the proliferation of human vascular endothelial cells as compared to those from healthy donors or MGUS patients [112]. A very recent paper has suggested that fibronectin on the surface of MM cell-derived exosomes binds to heparin sulfate on endothelial cells thereby mediating MM exosome-BM cell interactions [131].

In $\mathrm{MM}$, increased osteoclastic activity together with suppressed osteoblastic activity is the main cause of osteolytic bone disease [132]. The differentiation and activation of osteoclasts are mainly mediated by osteoclast activating factors secreted by the MM cells or BMSCs in the BM $[1,132]$. The increased number and activity of osteoclasts further enhance MM cell growth and survival through cell-cell contact and secretion of IL-6 and B-cell-activating factor [133-135]. A recent paper has demonstrated MM cell-derived exosomes as mediators of osteoclast formation and activation [136]. MM-derived exosomes supported both survival and migration of osteoclast precursors, and induced their differentiation to osteoclasts, as well as their bone resorption activity. Moreover, exosomes obtained from the plasma of MM patients exhibited the same functions in osteoclast differentiation [136].

Interestingly, EVs can also directly promote MM cell proliferation in an autocrine manner. Specifically, EVs derived from CD147-overexpressing MM cells or MM patients enhance MM cell proliferation, while the growth promotion of EVs from CD147-downregulated cells was attenuated, suggesting that CD147 is partially involved in EV-induced cell proliferation [118].

Tumor-derived exosomes generally contain tumor antigens and therefore have attracted much attention for their potential use as vaccines [137-139]. These exosomes still need the host DCs to present tumor antigens for the stimulation of antitumor immunity [140-142]. The antitumor response mediated by MM cell-derived exosomes was examined after engineering modifications. Exosomes released by MM cells engineered to express TNF- $\alpha$ induced a more efficient tumor antigen-specific $\mathrm{CD}^{+} \mathrm{T}$ cell response in mice and protected all the experimental mice from tumor growth [143]. Exosomes collected from MM cells overexpressing membrane-bound Hsp70 stimulated maturation of DCs and upregulated the presence of several membrane molecules such as $1 \mathrm{a}^{\mathrm{d}}$, CD40, and CD80, as well as the secretion of inflammatory cytokines such as IL-1 $\beta$, IL-12, IFN- $\gamma$, and TNF- $\alpha$ [144]. Moreover, these engineered MM cell-derived exosomes stimulated a type $1 \mathrm{CD}^{+} \mathrm{T}$ cell response in mice and protected tumor-bearing mice from death through induction of strong $\mathrm{CD}^{+}$cytotoxic $\mathrm{T}$ lymphocyte (CTL) responses and NK cell-mediated antitumor immunity [144].

Taken together, MM cell-derived EVs seem to enhance angiogenesis and osteoclastic activity in the BM, hereby establishing a favorable microenvironment and ultimately favoring MM progression (Figure 2).

\section{Function of stromal cell-derived EVs}

BMSCs play crucial roles in MM progression and induction of drug resistance through cell-cell contact and secretion of cytokines [1, 145, 146]. MM cells adhere to BMSCs, stimulating the latter to secrete more soluble factors which mediate MM cell growth, survival, migration, drug resistance, and BM angiogenesis [145, 147-151]. Roccaro et al. and our group have demonstrated exosomes as novel communicators and regulators in the interactions between MM cells and stromal cells [152, 153].

The content of BM-MSC-derived exosomes from MM patients was analyzed by miRNA and protein arrays, showing a lower level of the tumor suppressor miR-15a and higher levels of oncogenic proteins, cytokines, and adhesion molecules compared to healthy BM-MSCs 
[152]. The inability of exosomal miR-15a transfer from tumoral BM-MSCs to MM cells partially contributed to the increased tumor burden in a murine MM model, since low levels of miR-15a were unable to keep MM cell proliferation [152]. Many cytokines including IL-1ra, interferon-inducible protein 10 , monocyte chemoattractant protein 1 (MCP-1), macrophage inflammatory protein$1 \alpha$ (MIP-1 $\alpha)$, MIP-1 $\beta$, and stromal cell-derived factor 1 (SDF-1) were detected by our group in murine MM BMSC-derived exosomes [153]. We found that these exosomes carrying functional miRNA or proteins could be taken up by MM cells and induce their proliferation, survival, and migration, as well as drug resistance to bortezomib, a widely used and efficient clinical drug for MM treatment [153]. These findings highlight the roles of stromal cell-derived exosomes in supporting MM pathogenesis and progression. Additionally we identified an indirect approach to favor MM progression by stromal cell-secreted exosomes [154]. BMSC-derived exosomes could be taken up not only by MM cells but also by MDSCs in the BM and activate these MDSCs through
STAT3 and STAT1 pathways. Moreover, these exosomes promoted the survival of MDSCs in the BM and enhanced their immunosuppressive functions, thus favoring MM progression [154].

Overall, exosomes secreted from MM cells and BM-derived cells potentially play important roles in the modification of the BM microenvironment and are involved in the maintenance of a vicious cycle between normal BM cells and MM cells (Figure 2). However, the cross talks between MM cells and other important BM-derived cells such as DCs, macrophages, and hematopoietic stem cells through EVs, especially exosomes, still need to be elucidated for a better understanding of the BM microenvironmental changes during MM progression.

\section{Potential therapeutic implications of EVs in MM}

Despite substantial improvement in survival of MM patients over the past decade, innovative therapeutic

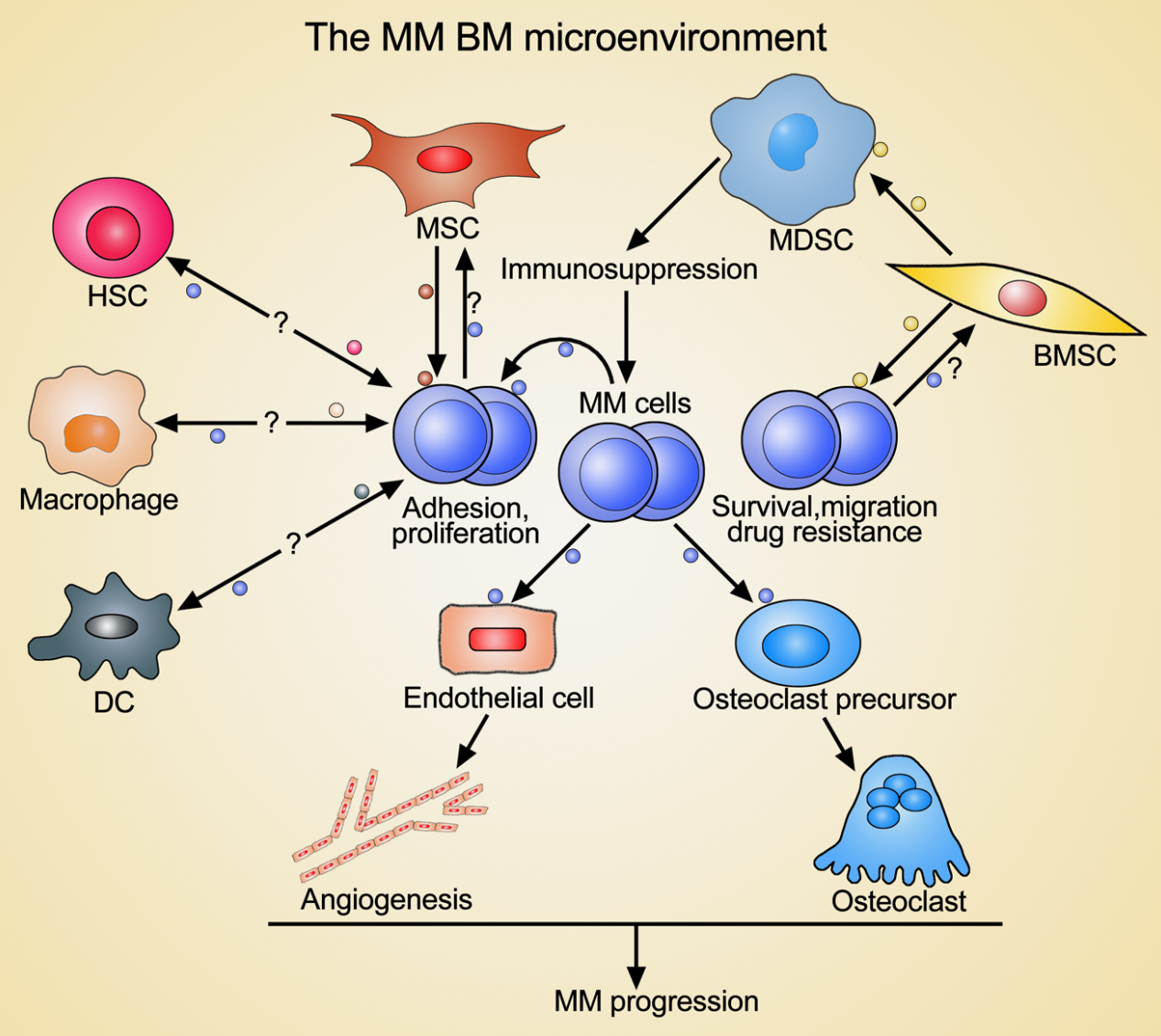

Figure 2: Crosstalk between MM cells and BM-derived cells through extracellular vesicles (EVs). MM cell-derived EVs modify the BM microenvironment through enhancing angiogenesis and promoting osteoclast differentiation and activation. BMSCs and MSC-derived EVs directly promote MM cell adhesion, proliferation, and survival, and induce drug resistance. BMSC-derived EVs indirectly facilitate MM progression through activating MDSCs and inducing immunosuppression. However, the effects of MM cellderived EVs on MSC and BMSC, as well as the EVs-mediated interactions between MM cells and other important BM-derived cells such as hematopoietic stem cells (HSCs), macrophages, and dendritic cells (DCs), still need to be investigated. 
strategies are still needed to prolong progression-free and overall survival and to potentially increase cure rate. Most innovations in drug therapy have been the result of a better understanding of MM biology leading to the recognition of new drug targets. We believe that knowledge on MM associated EVs will be a valuable asset to develop new therapies, since they seem to have a wide range of biological effects related to the BM micro-environment and anti-tumor immunity.

$\mathrm{DC}$ based vaccination in relapsed $\mathrm{MM}$ is the subject of several recent and ongoing clinical trials [155-161]. As mentioned above, exosomes are a potential candidate for use in these vaccination strategies. Tumor-derived exosomes have been shown to be immunogenic and contain targets for DC vaccination in lymphoma [162] and melanoma [163]. Furthermore dexosomes could in theory, be easier to handle than DCs, while retaining the same potential for tumor vaccination. This has been the subject of various clinical trials [164-166], but the induced immune responses seem to be dependent on additional factors creating either an immune stimulatory or an immune suppressive environment [167].

On the other hand, tumor-derived exosomes can be responsible for evading antibody-based therapy. It has been shown in lymphoma that CD20-carrying exosomes can bind the therapeutic anti-CD20-antibodies (Rituximab) [168] and thereby prevent lymphoma cell death by both antibody-dependent cell cytotoxicity (ADCC) and complement-dependent cytotoxicity (CDC). Already three hours after Rituximab infusion in lymphoma patients, one third to one half of the Rituximab present in the plasma was bound to these lymphoma-derived exosomes, and thus deemed ineffective [169]. The same protective effect was observed in breast cancer, where HER2 positive breast cancer-derived exosomes shield the tumor cells from the therapeutic effects of the anti-HER2 antibody Trastuzumab [170]. One could argue that MMderived EVs might be responsible for a reduced effect of the new monoclonal antibody therapies eg. Daratumumab, Elotuzumab or Indatuximab Ravtansine in a similar way, by acting as a decoy for the antibodies.

Since tumor-derived exosomes can seemingly suppress the anti-tumor response and aid in a tumorfriendly microenvironment, research is ongoing on how to block the secretion of these exosomes, or eradicate them from the patient. Multiple inhibitors which block the release of EVs, such as GW4869, spiroepoxide, dimethyl amiloride, and manumycin-A, have been studied in vitro [171-173]. However these inhibitors are not specific and have too much off-target effects to be therapeutically practical. A better option might be to remove tumorderived exosomes from the patient by using extracorporal hemofiltration [174].

\section{Perspectives}

Although compelling studies have focused on the targets and functions of EVs secreted by many BM-derived cells and on the important role of EVs in the immune response, tumor progression, vaccine development, and treatment of various diseases, the complete crosstalk between these BM cells through EVs is still not fully elucidated. This is especially complex as the functions of EVs from many other BM cell types including endothelial cells, osteoclasts, osteoblasts, hematopoietic stem cells, NK cells, and lymphocytes are still not clear. Furthermore, other types of EVs such as oncosomes have not been studied yet in the BM microenvironment. Oncosomes are a subpopulation of membranous large MVs derived from cancer cells that are characterized by the ability to transfer oncogenic signals and protein complexes [175, 176]. The transfer of oncogene-containing oncosomes results in transformation-like changes in recipient cells $[175,177]$ and can induce phenotypic reprogramming of other normal cells [178, 179]. Therefore, further studies examining the role of EVs, including oncosomes in the BM crosstalk would help increase our understanding of the BM involvement in multiple disease types. Moreover, finding better ways to block pathological exosome secretion would benefit the development of novel therapies for cancers such as MM.

\section{ACKNOWLEDGMENTS}

This work was supported by fonds voor wetenschappelijk onderzoek (FWO-VI) and Kom op tegen Kanker (KotK). J. Wang was supported by a China Scholarship Council (CSC)-VUB scholarship. S. Faict is a $\mathrm{PhD}$ student supported by FWO-VI. E. Menu is a postdoctoral fellow of AXA Research Fund. K. Maes, E. Van Valckenborgh and E. De Bruyne are postdoctoral fellows of FWO-VI.

\section{Authors' contributions}

E. Menu, K. Vanderkerken and J. Wang conceived this review; J. Wang and S. Faict wrote the manuscript; J. Wang drew the figures; K. Maes, E. Van Valckenborgh, E. De Bruyne, R. Schots, K. Vanderkerken and E. Menu, provided crucial suggestions and revised the manuscript.

\section{CONFLICTS OF INTEREST}

The authors declare no conflict of interest.

\section{REFERENCES}

1. Lemaire M, Deleu S, De Bruyne E, Van Valckenborgh E, 
Menu E and Vanderkerken K. The microenvironment and molecular biology of the multiple myeloma tumor. Adv Cancer Res. 2011; 110:19-42.

2. Fooksman DR, Vardhana S, Vasiliver-Shamis G, Liese J, Blair DA, Waite J, Sacristan C, Victora GD, Zanin-Zhorov A and Dustin ML. Functional anatomy of T cell activation and synapse formation. Annu Rev Immunol. 2010; 28:79105.

3. Hwang I. Cell-cell communication via extracellular membrane vesicles and its role in the immune response. Mol Cells. 2013; 36(2):105-111.

4. Camussi G, Deregibus MC, Bruno S, Grange C, Fonsato $\mathrm{V}$ and Tetta C. Exosome/microvesicle-mediated epigenetic reprogramming of cells. Am J Cancer Res. 2011; 1(1):98110.

5. Raposo $G$ and Stoorvogel W. Extracellular vesicles: exosomes, microvesicles, and friends. J Cell Biol. 2013; 200(4):373-383.

6. Raimondo F, Morosi L, Chinello C, Magni F and Pitto M. Advances in membranous vesicle and exosome proteomics improving biological understanding and biomarker discovery. Proteomics. 2011; 11(4):709-720.

7. Johnstone RM, Adam M, Hammond JR, Orr L and Turbide C. Vesicle formation during reticulocyte maturation. Association of plasma membrane activities with released vesicles (exosomes). J Biol Chem. 1987; 262(19):94129420 .

8. Thery C, Zitvogel L and Amigorena S. Exosomes: composition, biogenesis and function. Nat Rev Immunol. 2002; 2(8):569-579.

9. Kharaziha P, Ceder S, Li Q and Panaretakis T. Tumor cellderived exosomes: a message in a bottle. Biochimica et biophysica acta. 2012; 1826(1):103-111.

10. Klumperman J and Raposo G. The complex ultrastructure of the endolysosomal system. Cold Spring Harbor perspectives in biology. 2014; 6(10):a016857.

11. Stuffers S, Sem Wegner C, Stenmark H and Brech A. Multivesicular endosome biogenesis in the absence of ESCRTs. Traffic. 2009; 10(7):925-937.

12. Kowal J, Tkach M and Thery C. Biogenesis and secretion of exosomes. Current opinion in cell biology. 2014; 29:116125.

13. Nabhan JF, Hu R, Oh RS, Cohen SN and Lu Q. Formation and release of arrestin domain-containing protein 1-mediated microvesicles (ARMMs) at plasma membrane by recruitment of TSG101 protein. Proceedings of the National Academy of Sciences of the United States of America. 2012; 109(11):4146-4151.

14. Baietti MF, Zhang Z, Mortier E, Melchior A, Degeest G, Geeraerts A, Ivarsson Y, Depoortere F, Coomans C, Vermeiren E, Zimmermann P and David G. Syndecansyntenin-ALIX regulates the biogenesis of exosomes. Nature cell biology. 2012; 14(7):677-685.

15. Kosaka N, Iguchi H, Yoshioka Y, Takeshita F, Matsuki
Y and Ochiya T. Secretory mechanisms and intercellular transfer of microRNAs in living cells. J Biol Chem. 2010; 285(23):17442-17452.

16. Trajkovic K, Hsu C, Chiantia S, Rajendran L, Wenzel D, Wieland F, Schwille P, Brugger B and Simons M. Ceramide triggers budding of exosome vesicles into multivesicular endosomes. Science. 2008; 319(5867):1244-1247.

17. Thery C, Ostrowski M and Segura E. Membrane vesicles as conveyors of immune responses. Nat Rev Immunol. 2009; 9(8):581-593.

18. Valadi H, Ekstrom K, Bossios A, Sjostrand M, Lee JJ and Lotvall JO. Exosome-mediated transfer of mRNAs and microRNAs is a novel mechanism of genetic exchange between cells. Nature cell biology. 2007; 9(6):654-659.

19. Bobrie A, Colombo M, Raposo G and Thery C. Exosome secretion: molecular mechanisms and roles in immune responses. Traffic. 2011; 12(12):1659-1668.

20. Liu C, Yu S, Zinn K, Wang J, Zhang L, Jia Y, Kappes JC, Barnes S, Kimberly RP, Grizzle WE and Zhang HG. Murine mammary carcinoma exosomes promote tumor growth by suppression of NK cell function. J Immunol. 2006; 176(3):1375-1385.

21. van Balkom BW, de Jong OG, Smits M, Brummelman J, den Ouden K, de Bree PM, van Eijndhoven MA, Pegtel DM, Stoorvogel W, Wurdinger $\mathrm{T}$ and Verhaar MC. Endothelial cells require miR-214 to secrete exosomes that suppress senescence and induce angiogenesis in human and mouse endothelial cells. Blood. 2013; 121(19):3997-4006, S3991-3915.

22. Lee HD, Kim YH and Kim DS. Exosomes derived from human macrophages suppress endothelial cell migration by controlling integrin trafficking. Eur J Immunol. 2014; 44:1156-69.

23. Sheldon H, Heikamp E, Turley H, Dragovic R, Thomas P, Oon CE, Leek R, Edelmann M, Kessler B, Sainson RC, Sargent I, Li JL and Harris AL. New mechanism for Notch signaling to endothelium at a distance by Delta-like 4 incorporation into exosomes. Blood. 2010; 116(13):23852394.

24. Cai Z, Yang F, Yu L, Yu Z, Jiang L, Wang Q, Yang Y, Wang L, Cao $\mathrm{X}$ and Wang J. Activated $\mathrm{T}$ cell exosomes promote tumor invasion via Fas signaling pathway. J Immunol. 2012; 188(12):5954-5961.

25. Gu J, Qian H, Shen L, Zhang X, Zhu W, Huang L, Yan Y, Mao F, Zhao C, Shi Y and Xu W. Gastric cancer exosomes trigger differentiation of umbilical cord derived mesenchymal stem cells to carcinoma-associated fibroblasts through TGF-beta/Smad pathway. PLoS One. 2012; 7(12):e52465.

26. Peinado H, Aleckovic M, Lavotshkin S, Matei I, CostaSilva B, Moreno-Bueno G, Hergueta-Redondo M, Williams C, Garcia-Santos G, Ghajar C, Nitadori-Hoshino A, Hoffman C, Badal K, Garcia BA, Callahan MK, Yuan J, et al. Melanoma exosomes educate bone marrow progenitor 
cells toward a pro-metastatic phenotype through MET. Nat Med. 2012; 18(6):883-891.

27. Ratajczak J, Wysoczynski M, Hayek F, JanowskaWieczorek A and Ratajczak MZ. Membrane-derived microvesicles: important and underappreciated mediators of cell-to-cell communication. Leukemia. 2006; 20(9):14871495.

28. Liu Y, Xiang X, Zhuang X, Zhang S, Liu C, Cheng Z, Michalek S, Grizzle W and Zhang HG. Contribution of MyD88 to the tumor exosome-mediated induction of myeloid derived suppressor cells. Am J Pathol. 2010; 176(5):2490-2499.

29. Jung T, Castellana D, Klingbeil P, Cuesta Hernandez I, Vitacolonna M, Orlicky DJ, Roffler SR, Brodt P and Zoller M. CD44v6 dependence of premetastatic niche preparation by exosomes. Neoplasia. 2009; 11(10):1093-1105.

30. Yeo RW, Lai RC, Zhang B, Tan SS, Yin Y, Teh BJ and Lim SK. Mesenchymal stem cell: an efficient mass producer of exosomes for drug delivery. Advanced drug delivery reviews. 2013; 65(3):336-341.

31. Baglio SR, Rooijers K, Koppers-Lalic D, Verweij FJ, Perez Lanzon M, Zini N, Naaijkens B, Perut F, Niessen HW, Baldini N and Pegtel DM. Human bone marrow- and adipose-mesenchymal stem cells secrete exosomes enriched in distinctive miRNA and tRNA species. Stem cell research \& therapy. 2015; 6:127.

32. Collino F, Deregibus MC, Bruno S, Sterpone L, Aghemo G, Viltono L, Tetta C and Camussi G. Microvesicles derived from adult human bone marrow and tissue specific mesenchymal stem cells shuttle selected pattern of miRNAs. PLoS One. 2010; 5(7):e11803.

33. Tomasoni S, Longaretti L, Rota C, Morigi M, Conti S, Gotti E, Capelli C, Introna M, Remuzzi G and Benigni A. Transfer of growth factor receptor mRNA via exosomes unravels the regenerative effect of mesenchymal stem cells. Stem cells and development. 2013; 22(5):772-780.

34. Vallabhaneni KC, Penfornis P, Dhule S, Guillonneau F, Adams KV, Mo YY, Xu R, Liu Y, Watabe K, Vemuri $\mathrm{MC}$ and Pochampally R. Extracellular vesicles from bone marrow mesenchymal stem/stromal cells transport tumor regulatory microRNA, proteins, and metabolites. Oncotarget. 2015; 6(7):4953-4967. doi: 10.18632/ oncotarget.3211.

35. Favaro E, Carpanetto A, Lamorte S, Fusco A, Caorsi C, Deregibus MC, Bruno S, Amoroso A, Giovarelli M, Porta M, Perin PC, Tetta C, Camussi G and Zanone MM. Human mesenchymal stem cell-derived microvesicles modulate $\mathrm{T}$ cell response to islet antigen glutamic acid decarboxylase in patients with type 1 diabetes. Diabetologia. 2014; 57(8):1664-1673.

36. Del Fattore A, Luciano R, Pascucci L, Goffredo BM, Giorda E, Scapaticci M, Fierabracci A and Muraca M. Immunoregulatory effects of Mesenchymal Stem Cellderived Extracellular Vesicles on T lymphocytes. Cell transplantation. 2015; 24(12):2615-27.
37. Kordelas L, Rebmann V, Ludwig AK, Radtke S, Ruesing J, Doeppner TR, Epple M, Horn PA, Beelen DW and Giebel B. MSC-derived exosomes: a novel tool to treat therapyrefractory graft-versus-host disease. Leukemia. 2014; 28(4):970-973.

38. Bian S, Zhang L, Duan L, Wang X, Min Y and Yu H. Extracellular vesicles derived from human bone marrow mesenchymal stem cells promote angiogenesis in a rat myocardial infarction model. J Mol Med (Berl). 2014; 92(4):387-397.

39. He J, Wang Y, Sun S, Yu M, Wang C, Pei X, Zhu B, Wu J and Zhao W. Bone marrow stem cells-derived microvesicles protect against renal injury in the mouse remnant kidney model. Nephrology (Carlton). 2012; 17(5):493-500.

40. Ono M, Kosaka N, Tominaga N, Yoshioka Y, Takeshita F, Takahashi RU, Yoshida M, Tsuda H, Tamura K and Ochiya T. Exosomes from bone marrow mesenchymal stem cells contain a microRNA that promotes dormancy in metastatic breast cancer cells. Science signaling. 2014; 7(332):ra63.

41. Lim PK, Bliss SA, Patel SA, Taborga M, Dave MA, Gregory LA, Greco SJ, Bryan M, Patel PS and Rameshwar P. Gap junction-mediated import of microRNA from bone marrow stromal cells can elicit cell cycle quiescence in breast cancer cells. Cancer Res. 2011; 71(5):1550-1560.

42. Zhu W, Huang L, Li Y, Zhang X, Gu J, Yan Y, Xu X, Wang $\mathrm{M}$, Qian $\mathrm{H}$ and $\mathrm{Xu} \mathrm{W}$. Exosomes derived from human bone marrow mesenchymal stem cells promote tumor growth in vivo. Cancer letters. 2012; 315(1):28-37.

43. Bruno S, Collino F, Deregibus MC, Grange C, Tetta C and Camussi G. Microvesicles derived from human bone marrow mesenchymal stem cells inhibit tumor growth. Stem cells and development. 2013; 22(5):758-771.

44. Del Fattore A, Luciano R, Saracino R, Battafarano G, Rizzo C, Pascucci L, Alessandri G, Pessina A, Perrotta A, Fierabracci A and Muraca M. Differential effects of extracellular vesicles secreted by mesenchymal stem cells from different sources on glioblastoma cells. Expert opinion on biological therapy. 2015; 15(4):495-504.

45. Tan JK and O'Neill HC. Maturation requirements for dendritic cells in $\mathrm{T}$ cell stimulation leading to tolerance versus immunity. Journal of leukocyte biology. 2005; 78(2):319-324.

46. Ganguly D, Haak S, Sisirak V and Reizis B. The role of dendritic cells in autoimmunity. Nature reviews Immunology. 2013; 13(8):566-577.

47. Chaput N, Flament C, Viaud S, Taieb J, Roux S, Spatz A, Andre F, LePecq JB, Boussac M, Garin J, Amigorena S, Thery $\mathrm{C}$ and Zitvogel L. Dendritic cell derived-exosomes: biology and clinical implementations. Journal of leukocyte biology. 2006; 80(3):471-478.

48. Zitvogel L, Regnault A, Lozier A, Wolfers J, Flament C, Tenza D, Ricciardi-Castagnoli P, Raposo G and Amigorena $\mathrm{S}$. Eradication of established murine tumors using a novel cell-free vaccine: dendritic cell-derived exosomes. Nat 
Med. 1998; 4(5):594-600.

49. Viaud S, Terme M, Flament C, Taieb J, Andre F, Novault S, Escudier B, Robert C, Caillat-Zucman S, Tursz T, Zitvogel L and Chaput N. Dendritic cell-derived exosomes promote natural killer cell activation and proliferation: a role for NKG2D ligands and IL-15Ralpha. PLoS One. 2009; 4(3):e4942.

50. Simhadri VR, Reiners KS, Hansen HP, Topolar D, Simhadri VL, Nohroudi K, Kufer TA, Engert A and Pogge von Strandmann E. Dendritic cells release HLA-B-associated transcript-3 positive exosomes to regulate natural killer function. PLoS One. 2008; 3(10):e3377.

51. Thery C, Duban L, Segura E, Veron P, Lantz O and Amigorena $\mathrm{S}$. Indirect activation of naive CD4+ T cells by dendritic cell-derived exosomes. Nature immunology. 2002; 3(12):1156-1162.

52. Gehrmann U, Hiltbrunner S, Georgoudaki AM, Karlsson MC, Naslund TI and Gabrielsson S. Synergistic induction of adaptive antitumor immunity by codelivery of antigen with alpha-galactosylceramide on exosomes. Cancer Res. 2013; 73(13):3865-3876.

53. Qazi KR, Gehrmann U, Domange Jordo E, Karlsson MC and Gabrielsson S. Antigen-loaded exosomes alone induce Th1-type memory through a B-cell-dependent mechanism. Blood. 2009; 113(12):2673-2683.

54. Naslund TI, Gehrmann U, Qazi KR, Karlsson MC and Gabrielsson S. Dendritic cell-derived exosomes need to activate both $\mathrm{T}$ and $\mathrm{B}$ cells to induce antitumor immunity. J Immunol. 2013; 190(6):2712-2719.

55. Utsugi-Kobukai S, Fujimaki H, Hotta C, Nakazawa M and Minami M. MHC class I-mediated exogenous antigen presentation by exosomes secreted from immature and mature bone marrow derived dendritic cells. Immunology letters. 2003; 89(2-3):125-131.

56. Bu N, Wu HQ, Zhang GL, Zhan SQ, Zhang R, Fan QY, Li YL, Zhai YF and Ren HW. Immature dendritic cell exosomes suppress experimental autoimmune myasthenia gravis. Journal of neuroimmunology. 2015; 285:71-75.

57. Yang X, Meng S, Jiang H, Zhu C and Wu W. Exosomes derived from immature bone marrow dendritic cells induce tolerogenicity of intestinal transplantation in rats. The Journal of surgical research. 2011; 171(2):826-832.

58. Li X, Li JJ, Yang JY, Wang DS, Zhao W, Song WJ, Li WM, Wang JF, Han W, Zhang ZC, Yu Y, Cao DY and Dou KF. Tolerance induction by exosomes from immature dendritic cells and rapamycin in a mouse cardiac allograft model. PLoS One. 2012; 7(8):e44045.

59. Peche H, Heslan M, Usal C, Amigorena S and Cuturi MC. Presentation of donor major histocompatibility complex antigens by bone marrow dendritic cell-derived exosomes modulates allograft rejection. Transplantation. 2003; 76(10):1503-1510.

60. Peche H, Renaudin K, Beriou G, Merieau E, Amigorena $\mathrm{S}$ and Cuturi MC. Induction of tolerance by exosomes and short-term immunosuppression in a fully MHCmismatched rat cardiac allograft model. American journal of transplantation. 2006; 6(7):1541-1550.

61. Veron P, Segura E, Sugano G, Amigorena S and Thery C. Accumulation of MFG-E8/lactadherin on exosomes from immature dendritic cells. Blood cells, molecules \& diseases. 2005; 35(2):81-88.

62. Miksa M, Wu R, Dong W, Das P, Yang D and Wang P. Dendritic cell-derived exosomes containing milk fat globule epidermal growth factor-factor VIII attenuate proinflammatory responses in sepsis. Shock. 2006; 25(6):586-593.

63. Kim SH, Lechman ER, Bianco N, Menon R, Keravala A, Nash J, Mi Z, Watkins SC, Gambotto A and Robbins PD. Exosomes derived from IL-10-treated dendritic cells can suppress inflammation and collagen-induced arthritis. J Immunol. 2005; 174(10):6440-6448.

64. Yang X, Meng S, Jiang H, Chen T and Wu W. Exosomes derived from interleukin-10-treated dendritic cells can inhibit trinitrobenzene sulfonic acid-induced rat colitis. Scandinavian journal of gastroenterology. 2010; 45(10):1168-1177.

65. Kim SH, Bianco N, Menon R, Lechman ER, Shufesky WJ, Morelli AE and Robbins PD. Exosomes derived from genetically modified DC expressing FasL are antiinflammatory and immunosuppressive. Molecular therapy. 2006; 13(2):289-300.

66. Kim SH, Bianco NR, Shufesky WJ, Morelli AE and Robbins PD. Effective treatment of inflammatory disease models with exosomes derived from dendritic cells genetically modified to express IL-4. J Immunol. 2007; 179(4):2242-2249.

67. Bianco NR, Kim SH, Ruffner MA and Robbins PD. Therapeutic effect of exosomes from indoleamine 2,3-dioxygenase-positive dendritic cells in collagen-induced arthritis and delayed-type hypersensitivity disease models. Arthritis and rheumatism. 2009; 60(2):380-389.

68. Quah BJ and O'Neill HC. The immunogenicity of dendritic cell-derived exosomes. Blood cells, molecules \& diseases. 2005; 35(2):94-110.

69. Morelli AE. The immune regulatory effect of apoptotic cells and exosomes on dendritic cells: its impact on transplantation. American journal of transplantation. 2006; 6(2):254-261.

70. Cronemberger-Andrade A, Aragao-Franca L, de Araujo $\mathrm{CF}$, Rocha VJ, Borges-Silva Mda C, Figueira CP, Oliveira PR, de Freitas LA, Veras PS and Pontes-de-Carvalho L. Extracellular vesicles from Leishmania-infected macrophages confer an anti-infection cytokine-production profile to naive macrophages. PLoS neglected tropical diseases. 2014; 8(9):e3161.

71. Giri PK and Schorey JS. Exosomes derived from M. Bovis BCG infected macrophages activate antigen-specific CD4+ and CD8+ T cells in vitro and in vivo. PLoS One. 2008; 
3(6):e2461.

72. Singh PP, Smith VL, Karakousis PC and Schorey JS. Exosomes isolated from mycobacteria-infected mice or cultured macrophages can recruit and activate immune cells in vitro and in vivo. J Immunol. 2012; 189(2):777-785.

73. Singh PP, LeMaire C, Tan JC, Zeng E and Schorey JS. Exosomes released from M. tuberculosis infected cells can suppress IFN-gamma mediated activation of naive macrophages. PLoS One. 2011; 6(4):e18564.

74. Skokos D, Le Panse S, Villa I, Rousselle JC, Peronet R, David B, Namane A and Mecheri S. Mast cell-dependent $\mathrm{B}$ and $\mathrm{T}$ lymphocyte activation is mediated by the secretion of immunologically active exosomes. J Immunol. 2001; 166(2):868-876.

75. Skokos D, Le Panse S, Villa I, Rousselle JC, Peronet R, Namane A, David B and Mecheri S. Nonspecific B and $\mathrm{T}$ cell-stimulatory activity mediated by mast cells is associated with exosomes. International archives of allergy and immunology. 2001; 124(1-3):133-136.

76. Martin PJ, Haren N, Ghali O, Clabaut A, Chauveau C, Hardouin P and Broux O. Adipogenic RNAs are transferred in osteoblasts via bone marrow adipocytes-derived extracellular vesicles (EVs). BMC cell biology. 2015; 16:10.

77. Kahlert $\mathrm{C}$ and Kalluri R. Exosomes in tumor microenvironment influence cancer progression and metastasis. J Mol Med (Berl). 2013; 91(4):431-437.

78. Milane L, Singh A, Mattheolabakis G, Suresh M and Amiji MM. Exosome mediated communication within the tumor microenvironment. J Control Release. 2015; 219:278-94.

79. Atay S and Godwin AK. Tumor-derived exosomes: A message delivery system for tumor progression. Commun Integr Biol. 2014; 7(1):e28231.

80. Hattori K, Dias S, Heissig B, Hackett NR, Lyden D, Tateno M, Hicklin DJ, Zhu Z, Witte L, Crystal RG, Moore MA and Rafii S. Vascular endothelial growth factor and angiopoietin-1 stimulate postnatal hematopoiesis by recruitment of vasculogenic and hematopoietic stem cells. J Exp Med. 2001; 193(9):1005-1014.

81. Yamaguchi J, Kusano KF, Masuo O, Kawamoto A, Silver M, Murasawa S, Bosch-Marce M, Masuda H, Losordo DW, Isner JM and Asahara T. Stromal cell-derived factor-1 effects on ex vivo expanded endothelial progenitor cell recruitment for ischemic neovascularization. Circulation. 2003; 107(9):1322-1328.

82. Kawada H, Fujita J, Kinjo K, Matsuzaki Y, Tsuma M, Miyatake H, Muguruma Y, Tsuboi K, Itabashi Y, Ikeda Y, Ogawa S, Okano H, Hotta T, Ando K and Fukuda K. Nonhematopoietic mesenchymal stem cells can be mobilized and differentiate into cardiomyocytes after myocardial infarction. Blood. 2004; 104(12):3581-3587.

83. De Veirman K, Van Valckenborgh E, Lahmar Q, Geeraerts X, De Bruyne E, Menu E, Van Riet I, Vanderkerken K and Van Ginderachter JA. Myeloid-derived suppressor cells as therapeutic target in hematological malignancies. Front Oncol. 2014; 4:349.

84. Diaz-Montero CM, Salem ML, Nishimura MI, GarrettMayer E, Cole DJ and Montero AJ. Increased circulating myeloid-derived suppressor cells correlate with clinical cancer stage, metastatic tumor burden, and doxorubicincyclophosphamide chemotherapy. Cancer Immunol Immunother. 2009; 58(1):49-59.

85. Gorgun GT, Whitehill G, Anderson JL, Hideshima T, Maguire C, Laubach J, Raje N, Munshi NC, Richardson PG and Anderson KC. Tumor-promoting immune-suppressive myeloid-derived suppressor cells in the multiple myeloma microenvironment in humans. Blood. 2013; 121(15):29752987.

86. Fremder E, Munster M, Aharon A, Miller V, Gingis-Velitski S, Voloshin T, Alishekevitz D, Bril R, Scherer SJ, Loven D, Brenner B and Shaked Y. Tumor-derived microparticles induce bone marrow-derived cell mobilization and tumor homing: a process regulated by osteopontin. Int J Cancer. 2014; 135(2):270-281.

87. Munster M, Fremder E, Miller V, Ben-Tsedek N, Davidi S, Scherer SJ and Shaked Y. Anti-VEGF-A affects the angiogenic properties of tumor-derived microparticles. PLoS One. 2014; 9(4):e95983.

88. Umezu T, Tadokoro H, Azuma K, Yoshizawa S, Ohyashiki $\mathrm{K}$ and Ohyashiki JH. Exosomal miR-135b shed from hypoxic multiple myeloma cells enhances angiogenesis by targeting factor-inhibiting HIF-1. Blood. 2014; 124(25):3748-3757.

89. Umezu T, Ohyashiki K, Kuroda M and Ohyashiki JH. Leukemia cell to endothelial cell communication via exosomal miRNAs. Oncogene. 2013; 32(22):2747-2755.

90. Tadokoro H, Umezu T, Ohyashiki K, Hirano $\mathrm{T}$ and Ohyashiki JH. Exosomes derived from hypoxic leukemia cells enhance tube formation in endothelial cells. J Biol Chem. 2013; 288(48):34343-34351.

91. Corrado C, Flugy AM, Taverna S, Raimondo S, Guggino G, Karmali R, De Leo G and Alessandro R. Carboxyamidotriazole-orotate inhibits the growth of imatinib-resistant chronic myeloid leukaemia cells and modulates exosomes-stimulated angiogenesis. PLoS One. 2012; 7(8):e42310.

92. Vinay DS, Ryan EP, Pawelec G, Talib WH, Stagg J, Elkord E, Lichtor T, Decker WK, Whelan RL, Kumara HM, Signori E, Honoki K, Georgakilas AG, Amin A, Helferich WG, Boosani $\mathrm{CS}$, et al. Immune evasion in cancer: Mechanistic basis and therapeutic strategies. Semin Cancer Biol. 2015; 35 Suppl:S185-98.

93. Xiang X, Poliakov A, Liu C, Liu Y, Deng ZB, Wang J, Cheng Z, Shah SV, Wang GJ, Zhang L, Grizzle WE, Mobley J and Zhang HG. Induction of myeloid-derived suppressor cells by tumor exosomes. Int J Cancer. 2009; 124(11):2621-2633.

94. Yu S, Liu C, Su K, Wang J, Liu Y, Zhang L, Li C, Cong Y, 
Kimberly R, Grizzle WE, Falkson C and Zhang HG. Tumor exosomes inhibit differentiation of bone marrow dendritic cells. J Immunol. 2007; 178(11):6867-6875.

95. Chalmin F, Ladoire S, Mignot G, Vincent J, Bruchard M, Remy-Martin JP, Boireau W, Rouleau A, Simon B, Lanneau D, De Thonel A, Multhoff G, Hamman A, Martin F, Chauffert B, Solary E, et al. Membrane-associated Hsp72 from tumor-derived exosomes mediates STAT3-dependent immunosuppressive function of mouse and human myeloidderived suppressor cells. J Clin Invest. 2010; 120(2):457471.

96. Madera L, Greenshields A, Coombs MR and Hoskin DW. 4T1 Murine Mammary Carcinoma Cells Enhance Macrophage-Mediated Innate Inflammatory Responses. PLoS One. 2015; 10(7):e0133385.

97. Marton A, Vizler C, Kusz E, Temesfoi V, Szathmary Z, Nagy K, Szegletes Z, Varo G, Siklos L, Katona RL, Tubak V, Howard OM, Duda E, Minarovits J and Buzas K. Melanoma cell-derived exosomes alter macrophage and dendritic cell functions in vitro. Immunology letters. 2012; 148(1):34-38.

98. Bretz NP, Ridinger J, Rupp AK, Rimbach K, Keller S, Rupp C, Marme F, Umansky L, Umansky V, Eigenbrod $\mathrm{T}$, Sammar $\mathrm{M}$ and Altevogt P. Body fluid exosomes promote secretion of inflammatory cytokines in monocytic cells via Toll-like receptor signaling. J Biol Chem. 2013; 288(51):36691-36702.

99. Ma B, Jiang H, Jia J, Di L, Song G, Yu J, Zhu Y, Lu Z, Wang X, Zhou X and Ren J. Murine bone marrow stromal cells pulsed with homologous tumor-derived exosomes inhibit proliferation of liver cancer cells. Clinical \& translational oncology. 2012; 14(10):764-773.

100. Corrado C, Raimondo S, Saieva L, Flugy AM, De Leo G and Alessandro R. Exosome-mediated crosstalk between chronic myelogenous leukemia cells and human bone marrow stromal cells triggers an interleukin 8-dependent survival of leukemia cells. Cancer letters. 2014; 348(12):71-76.

101. Chowdhury R, Webber JP, Gurney M, Mason MD, Tabi $\mathrm{Z}$ and Clayton A. Cancer exosomes trigger mesenchymal stem cell differentiation into pro-angiogenic and proinvasive myofibroblasts. Oncotarget. 2015; 6(2):715-731. doi: 10.18632/oncotarget.2711.

102. Haga H, Yan IK, Takahashi K, Wood J, Zubair A and Patel T. Tumour cell-derived extracellular vesicles interact with mesenchymal stem cells to modulate the microenvironment and enhance cholangiocarcinoma growth. Journal of extracellular vesicles. 2015; 4:24900.

103. Paggetti J, Haderk F, Seiffert M, Janji B, Distler U, Ammerlaan W, Kim YJ, Adam J, Lichter P, Solary E, Berchem $G$ and Moussay E. Exosomes released by chronic lymphocytic leukemia cells induce the transition of stromal cells into cancer-associated fibroblasts. Blood. 2015; 126(9):1106-1117.

104. Abdi J, Chen G and Chang H. Drug resistance in multiple myeloma: latest findings and new concepts on molecular mechanisms. Oncotarget. 2013; 4(12):2186-2207. doi: 10.18632/oncotarget.1497.

105. Munshi NC and Anderson KC. New strategies in the treatment of multiple myeloma. Clin Cancer Res. 2013; 19(13):3337-3344.

106. Taylor DD and Gercel-Taylor C. MicroRNA signatures of tumor-derived exosomes as diagnostic biomarkers of ovarian cancer. Gynecol Oncol. 2008; 110(1):13-21.

107. Ghosh AK, Secreto CR, Knox TR, Ding W, Mukhopadhyay $\mathrm{D}$ and Kay NE. Circulating microvesicles in B-cell chronic lymphocytic leukemia can stimulate marrow stromal cells: implications for disease progression. Blood. 2010; 115(9):1755-1764.

108. Di Noto G, Paolini L, Zendrini A, Radeghieri A, Caimi L and Ricotta D. C-src enriched serum microvesicles are generated in malignant plasma cell dyscrasia. PLoS One. 2013; 8(8):e70811.

109. Caivano A, Laurenzana I, De Luca L, La Rocca F, Simeon V, Trino S, D‘Auria F, Traficante A, Maietti M, Izzo T, D‘Arena G, Mansueto G, Pietrantuono G, Laurenti L, Musto $P$ and Del Vecchio L. High serum levels of extracellular vesicles expressing malignancy-related markers are released in patients with various types of hematological neoplastic disorders. Tumour Biol. 2015; 36:9739-52.

110. Quarona V, Ferri V, Chillemi A, Bolzoni M, Mancini C, Zaccarello G, Roato I, Morandi F, Marimpietri D, Faccani G, Martella E, Pistoia V, Giuliani N, Horenstein AL and Malavasi F. Unraveling the contribution of ectoenzymes to myeloma life and survival in the bone marrow niche. Annals of the New York Academy of Sciences. 2015; 1335:10-22.

111. Benameur T, Chappard D, Fioleau E, Andriantsitohaina R, Martinez MC, Clere N and Marchand-Libouban H. Plasma cells release membrane microparticles in a mouse model of multiple myeloma. Micron. 2013; 54-55:75-81.

112. Di Noto G, Chiarini M, Paolini L, Mazzoldi EL, Giustini V, Radeghieri A, Caimi L and Ricotta D. Immunoglobulin Free Light Chains and GAGs Mediate Multiple Myeloma Extracellular Vesicles Uptake and Secondary NfkappaB Nuclear Translocation. Front Immunol. 2014; 5:517.

113. Thompson CA, Purushothaman A, Ramani VC, Vlodavsky I and Sanderson RD. Heparanase regulates secretion, composition, and function of tumor cell-derived exosomes. J Biol Chem. 2013; 288(14):10093-10099.

114. Manier S, Avet-Loiseau H, Campigotto F, Salem K, Huynh D, Glavey S, Sacco A, Roccaro AM, Minvielle S, Moreau P, Facon T, Leleu X, Weller E and Ghobrial I. Circulating Exosomal microRNAs Are Prognostic Markers in Multiple Myeloma. Blood, 57th ASH Annual Meeting. 2015; 126 (23): 1770 .

115. Seckinger A, Meissner T, Moreaux J, Benes V, Hillengass J, Castoldi M, Zimmermann J, Ho AD, Jauch A, Goldschmidt $\mathrm{H}$, Klein B and Hose D. miRNAs in multiple myeloma - 
a survival relevant complex regulator of gene expression. Oncotarget. 2015; 6(36):39165-39183. doi: 10.18632/ oncotarget.5381.

116. Chen B, Morgan G, Barlogie B and Epstein J. Specific Exosomal microRNA Are Differentially Expressed Between High and Low-Risk Myeloma Suggesting They Are Pathogenically Important. Blood, 57th ASH Annual Meeting. 2015; 126 (23): 4189.

117. Harshman SW, Canella A, Ciarlariello PD, Rocci A, Agarwal K, Smith EM, Talabere T, Efebera YA, Hofmeister CC, Benson DM, Jr., Paulaitis ME, Freitas MA and Pichiorri F. Characterization of multiple myeloma vesicles by label-free relative quantitation. Proteomics. 2013; 13(20):3013-3029.

118. Arendt BK, Walters DK, Wu X, Tschumper RC and Jelinek DF. Multiple myeloma dell-derived microvesicles are enriched in CD147 expression and enhance tumor cell proliferation. Oncotarget. 2014; 5(14):5686-5699. doi: 10.18632/oncotarget.2159.

119. Liu Y, Zhu XJ, Zeng C, Wu PH, Wang HX, Chen ZC and Li QB. Microvesicles secreted from human multiple myeloma cells promote angiogenesis. Acta Pharmacol Sin. 2014; 35(2):230-238.

120. Vacca A, Ribatti D, Roncali L, Ranieri G, Serio G, Silvestris F and Dammacco F. Bone marrow angiogenesis and progression in multiple myeloma. Br J Haematol. 1994; 87(3):503-508.

121. Bhatti SS, Kumar L, Dinda AK and Dawar R. Prognostic value of bone marrow angiogenesis in multiple myeloma: use of light microscopy as well as computerized image analyzer in the assessment of microvessel density and total vascular area in multiple myeloma and its correlation with various clinical, histological, and laboratory parameters. Am J Hematol. 2006; 81(9):649-656.

122. Rajkumar SV, Mesa RA, Fonseca R, Schroeder G, Plevak MF, Dispenzieri A, Lacy MQ, Lust JA, Witzig TE, Gertz MA, Kyle RA, Russell SJ and Greipp PR. Bone marrow angiogenesis in 400 patients with monoclonal gammopathy of undetermined significance, multiple myeloma, and primary amyloidosis. Clin Cancer Res. 2002; 8(7):22102216.

123. Vacca A, Ribatti D, Roccaro AM, Ria R, Palermo L and Dammacco F. Bone marrow angiogenesis and plasma cell angiogenic and invasive potential in patients with active multiple myeloma. Acta Haematol. 2001; 106(4):162-169.

124. Ria R, Roccaro AM, Merchionne F, Vacca A, Dammacco F and Ribatti D. Vascular endothelial growth factor and its receptors in multiple myeloma. Leukemia. 2003; 17(10):1961-1966.

125. Kumar S, Witzig TE, Timm M, Haug J, Wellik L, Fonseca R, Greipp PR and Rajkumar SV. Expression of VEGF and its receptors by myeloma cells. Leukemia. 2003; 17(10):2025-2031.

126. Giuliani N, Colla S, Lazzaretti M, Sala R, Roti G, Mancini
C, Bonomini S, Lunghi P, Hojden M, Genestreti G, Svaldi M, Coser P, Fattori PP, Sammarelli G, Gazzola GC, Bataille $\mathrm{R}$, et al. Proangiogenic properties of human myeloma cells: production of angiopoietin-1 and its potential relationship to myeloma-induced angiogenesis. Blood. 2003; 102(2):638645.

127. Gupta D, Treon SP, Shima Y, Hideshima T, Podar K, Tai YT, Lin B, Lentzsch S, Davies FE, Chauhan D, Schlossman RL, Richardson P, Ralph P, Wu L, Payvandi F, Muller G, et al. Adherence of multiple myeloma cells to bone marrow stromal cells upregulates vascular endothelial growth factor secretion: therapeutic applications. Leukemia. 2001; 15(12):1950-1961.

128. Hose D, Moreaux J, Meissner T, Seckinger A, Goldschmidt H, Benner A, Mahtouk K, Hillengass J, Reme T, De Vos J, Hundemer M, Condomines M, Bertsch U, Rossi JF, Jauch A, Klein B, et al. Induction of angiogenesis by normal and malignant plasma cells. Blood. 2009; 114(1):128-143.

129. Colla S, Storti P, Donofrio G, Todoerti K, Bolzoni M, Lazzaretti M, Abeltino M, Ippolito L, Neri A, Ribatti D, Rizzoli V, Martella E and Giuliani N. Low bone marrow oxygen tension and hypoxia-inducible factor1alpha overexpression characterize patients with multiple myeloma: role on the transcriptional and proangiogenic profiles of CD138(+) cells. Leukemia. 2010; 24(11):19671970.

130. Storti P, Bolzoni M, Donofrio G, Airoldi I, Guasco D, Toscani D, Martella E, Lazzaretti M, Mancini C, Agnelli L, Patrene K, Maiga S, Franceschi V, Colla S, Anderson J, Neri A, et al. Hypoxia-inducible factor (HIF)-1alpha suppression in myeloma cells blocks tumoral growth in vivo inhibiting angiogenesis and bone destruction. Leukemia. 2013; 27(8):1697-1706.

131. Purushothaman A, Bandari SK, Liu J, Mobley JA, Brown $\mathrm{EE}$ and Sanderson RD. Fibronectin on the surface of myeloma cell-derived exosomes mediates exosome-cell interactions. J Biol Chem. 2015.

132. Hameed A, Brady JJ, Dowling P, Clynes M and O'Gorman P. Bone disease in multiple myeloma: pathophysiology and management. Cancer Growth Metastasis. 2014; 7:33-42.

133. Abe M, Hiura K, Wilde J, Shioyasono A, Moriyama K, Hashimoto T, Kido S, Oshima T, Shibata H, Ozaki S, Inoue $\mathrm{D}$ and Matsumoto T. Osteoclasts enhance myeloma cell growth and survival via cell-cell contact: a vicious cycle between bone destruction and myeloma expansion. Blood. 2004; 104(8):2484-2491.

134. Yaccoby S, Wezeman MJ, Henderson A, Cottler-Fox M, Yi Q, Barlogie B and Epstein J. Cancer and the microenvironment: myeloma-osteoclast interactions as a model. Cancer Res. 2004; 64(6):2016-2023.

135. Abe M, Kido S, Hiasa M, Nakano A, Oda A, Amou H and Matsumoto T. BAFF and APRIL as osteoclast-derived survival factors for myeloma cells: a rationale for TACIFc treatment in patients with multiple myeloma. Leukemia. 2006; 20(7):1313-1315. 
136. Raimondi L, De Luca A, Amodio N, Manno M, Raccosta S, Taverna S, Bellavia D, Naselli F, Fontana S, Schillaci O, Giardino R, Fini M, Tassone P, Santoro A, De Leo G, Giavaresi $\mathrm{G}$, et al. Involvement of multiple myeloma cellderived exosomes in osteoclast differentiation. Oncotarget. 2015; 6(15):13772-13789. doi: 10.18632/oncotarget.3830.

137. Andre F, Schartz NE, Chaput N, Flament C, Raposo G, Amigorena S, Angevin E and Zitvogel L. Tumor-derived exosomes: a new source of tumor rejection antigens. Vaccine. 2002; 20 Suppl 4:A28-31.

138. Natasha G, Gundogan B, Tan A, Farhatnia Y, Wu W, Rajadas $\mathrm{J}$ and Seifalian AM. Exosomes as immunotheranostic nanoparticles. Clin Ther. 2014; 36(6):820-829.

139. Tran TH, Mattheolabakis G, Aldawsari H and Amiji M. Exosomes as nanocarriers for immunotherapy of cancer and inflammatory diseases. Clin Immunol. 2015.

140. Hao S, Bai O, Yuan J, Qureshi M and Xiang J. Dendritic cell-derived exosomes stimulate stronger CD8+ CTL responses and antitumor immunity than tumor cell-derived exosomes. Cell Mol Immunol. 2006; 3(3):205-211.

141. Bu N, Wu H, Sun B, Zhang G, Zhan S, Zhang R and Zhou L. Exosome-loaded dendritic cells elicit tumorspecific CD8+ cytotoxic T cells in patients with glioma. J Neurooncol. 2011; 104(3):659-667.

142. Yao Y, Chen L, Wei W, Deng X, Ma L and Hao S. Tumor cell-derived exosome-targeted dendritic cells stimulate stronger CD8+ CTL responses and antitumor immunities. Biochem Biophys Res Commun. 2013; 436(1):60-65.

143. Xie Y, Bai O, Zhang H, Li W and Xiang J. Tumor necrosis factor gene-engineered J558 tumor cell-released exosomes stimulate tumor antigen P1A-specific CD8+ CTL responses and antitumor immunity. Cancer Biother Radiopharm. 2010; 25(1):21-28.

144. Xie Y, Bai O, Zhang H, Yuan J, Zong S, Chibbar R, Slattery K, Qureshi M, Wei Y, Deng Y and Xiang J. Membranebound HSP70-engineered myeloma cell-derived exosomes stimulate more efficient CD8(+) CTL- and NK-mediated antitumour immunity than exosomes released from heatshocked tumour cells expressing cytoplasmic HSP70. J Cell Mol Med. 2010; 14(11):2655-2666.

145. Ribatti D, Moschetta M and Vacca A. Microenvironment and multiple myeloma spread. Thromb Res. 2014; 133 Suppl 2:S102-106.

146. Cohen K, Flint N, Shalev S, Erez D, Baharal T, Davis PJ, Hercbergs A, Ellis M and Ashur-Fabian O. Thyroid hormone regulates adhesion, migration and matrix metalloproteinase 9 activity via alphavbeta3 integrin in myeloma cells. Oncotarget. 2014; 5(15):6312-6322. doi: 10.18632/oncotarget.2205.

147. Mahindra A, Hideshima T and Anderson KC. Multiple myeloma: biology of the disease. Blood Rev. 2010; 24 Suppl 1:S5-11.

148. Garcia-Gomez A, De Las Rivas J, Ocio EM, Diaz-
Rodriguez E, Montero JC, Martin M, Blanco JF, SanchezGuijo FM, Pandiella A, San Miguel JF and Garayoa M. Transcriptomic profile induced in bone marrow mesenchymal stromal cells after interaction with multiple myeloma cells: implications in myeloma progression and myeloma bone disease. Oncotarget. 2014; 5(18):8284-8305. doi: 10.18632/oncotarget.2058.

149. Seckinger A, Meissner T, Moreaux J, Goldschmidt H, Fuhler GM, Benner A, Hundemer M, Reme T, Shaughnessy JD, Jr., Barlogie B, Bertsch U, Hillengass J, Ho AD, Pantesco V, Jauch A, De Vos J, et al. Bone morphogenic protein 6: a member of a novel class of prognostic factors expressed by normal and malignant plasma cells inhibiting proliferation and angiogenesis. Oncogene. 2009; 28(44):3866-3879.

150. Mahtouk K, Moreaux J, Hose D, Reme T, Meissner T, Jourdan M, Rossi JF, Pals ST, Goldschmidt H and Klein B. Growth factors in multiple myeloma: a comprehensive analysis of their expression in tumor cells and bone marrow environment using Affymetrix microarrays. BMC cancer. 2010; 10:198.

151. Fuhler GM, Baanstra M, Chesik D, Somasundaram R, Seckinger A, Hose D, Peppelenbosch MP and Bos NA. Bone marrow stromal cell interaction reduces syndecan-1 expression and induces kinomic changes in myeloma cells. Experimental cell research. 2010; 316(11):1816-1828.

152. Roccaro AM, Sacco A, Maiso P, Azab AK, Tai YT, Reagan M, Azab F, Flores LM, Campigotto F, Weller E, Anderson KC, Scadden DT and Ghobrial IM. BM mesenchymal stromal cell-derived exosomes facilitate multiple myeloma progression. J Clin Invest. 2013; 123(4):1542-1555.

153. Wang J, Hendrix A, Hernot S, Lemaire M, De Bruyne E, Van Valckenborgh E, Lahoutte T, De Wever O, Vanderkerken K and Menu E. Bone marrow stromal cellderived exosomes as communicators in drug resistance in multiple myeloma cells. Blood. 2014; 124(4):555-566.

154. Wang J, De Veirman K, De Beule N, Maes K, De Bruyne E, Van Valckenborgh E, Vanderkerken K and Menu E. The bone marrow microenvironment enhances multiple myeloma progression by exosome-mediated activation of myeloid-derived suppressor cells. Oncotarget. 2015; 6(41):43992-4004. doi: 10.18632/oncotarget.6083.

155. Rosenblatt J, Avivi I, Vasir B, Uhl L, Munshi NC, Katz T, Dey BR, Somaiya P, Mills H, Campigotto F, Weller E, Joyce R, Levine JD, Tzachanis D, Richardson P, Laubach $\mathrm{J}$, et al. Vaccination with dendritic cell/tumor fusions following autologous stem cell transplant induces immunologic and clinical responses in multiple myeloma patients. Clin Cancer Res. 2013; 19(13):3640-3648.

156. Hobo W, Strobbe L, Maas F, Fredrix H, Greupink-Draaisma A, Esendam B, de Witte T, Preijers F, Levenga H, van Rees B, Raymakers R, Schaap N and Dolstra H. Immunogenicity of dendritic cells pulsed with MAGE3, Survivin and B-cell maturation antigen mRNA for vaccination of multiple myeloma patients. Cancer Immunol Immunother. 2013; 
62(8):1381-1392.

157. Rosenblatt J, Vasir B, Uhl L, Blotta S, Macnamara C, Somaiya P, Wu Z, Joyce R, Levine JD, Dombagoda D, Yuan YE, Francoeur K, Fitzgerald D, Richardson P, Weller E, Anderson K, et al. Vaccination with dendritic cell/ tumor fusion cells results in cellular and humoral antitumor immune responses in patients with multiple myeloma. Blood. 2011; 117(2):393-402.

158. Batchu RB, Moreno AM, Szmania SM, Bennett G, Spagnoli GC, Ponnazhagan S, Barlogie B, Tricot G and van Rhee F. Protein transduction of dendritic cells for NY-ESO-1based immunotherapy of myeloma. Cancer Res. 2005; 65(21):10041-10049.

159. van Rhee F, Szmania SM, Zhan F, Gupta SK, Pomtree M, Lin P, Batchu RB, Moreno A, Spagnoli G, Shaughnessy $\mathrm{J}$ and Tricot G. NY-ESO-1 is highly expressed in poorprognosis multiple myeloma and induces spontaneous humoral and cellular immune responses. Blood. 2005; 105(10):3939-3944.

160. Rollig C, Schmidt C, Bornhauser M, Ehninger G, Schmitz $\mathrm{M}$ and Auffermann-Gretzinger S. Induction of cellular immune responses in patients with stage-I multiple myeloma after vaccination with autologous idiotype-pulsed dendritic cells. J Immunother. 2011; 34(1):100-106.

161. Lacy MQ, Mandrekar S, Dispenzieri A, Hayman S, Kumar S, Buadi F, Dingli D, Litzow M, Wettstein P, Padley D, Kabat B, Gastineau D, Rajkumar SV and Gertz MA. Idiotype-pulsed antigen-presenting cells following autologous transplantation for multiple myeloma may be associated with prolonged survival. Am J Hematol. 2009; 84(12):799-802.

162. Yao Y, Wei W, Sun J, Chen L, Deng X, Ma L and Hao S. Proteomic analysis of exosomes derived from human lymphoma cells. European journal of medical research. $2015 ; 20: 8$.

163. Wolfers J, Lozier A, Raposo G, Regnault A, Thery C, Masurier C, Flament C, Pouzieux S, Faure F, Tursz T, Angevin E, Amigorena $\mathrm{S}$ and Zitvogel L. Tumor-derived exosomes are a source of shared tumor rejection antigens for CTL cross-priming. Nat Med. 2001; 7(3):297-303.

164. Narita M, Kanda T, Abe T, Uchiyama T, Iwafuchi M, Zheng Z, Liu A, Kaifu T, Kosugi S, Minagawa M, Itoh $\mathrm{K}$ and Takahashi $\mathrm{M}$. Immune responses in patients with esophageal cancer treated with SART1 peptide-pulsed dendritic cell vaccine. International journal of oncology. 2015; 46(4):1699-1709.

165. Escudier B, Dorval T, Chaput N, Andre F, Caby MP, Novault S, Flament C, Leboulaire C, Borg C, Amigorena $\mathrm{S}$, Boccaccio C, Bonnerot C, Dhellin O, Movassagh M, Piperno S, Robert C, et al. Vaccination of metastatic melanoma patients with autologous dendritic cell (DC) derived-exosomes: results of thefirst phase I clinical trial. Journal of translational medicine. 2005; 3(1):10.

166. Morse MA, Garst J, Osada T, Khan S, Hobeika A, Clay TM, Valente N, Shreeniwas R, Sutton MA, Delcayre A,
Hsu DH, Le Pecq JB and Lyerly HK. A phase I study of dexosome immunotherapy in patients with advanced nonsmall cell lung cancer. Journal of translational medicine. 2005; 3(1):9.

167. Kunigelis KE and Graner MW. The Dichotomy of Tumor Exosomes (TEX) in Cancer Immunity: Is It All in the ConTEXt? Vaccines. 2015; 3(4):1019-1051.

168. Oksvold MP, Kullmann A, Forfang L, Kierulf B, Li M, Brech A, Vlassov AV, Smeland EB, Neurauter A and Pedersen KW. Expression of B-cell surface antigens in subpopulations of exosomes released from B-cell lymphoma cells. Clin Ther. 2014; 36(6):847-862 e841.

169. Aung T, Chapuy B, Vogel D, Wenzel D, Oppermann M, Lahmann M, Weinhage T, Menck K, Hupfeld T, Koch R, Trumper L and Wulf GG. Exosomal evasion of humoral immunotherapy in aggressive B-cell lymphoma modulated by ATP-binding cassette transporter A3. Proceedings of the National Academy of Sciences of the United States of America. 2011; 108(37):15336-15341.

170. Ciravolo V, Huber V, Ghedini GC, Venturelli E, Bianchi F, Campiglio M, Morelli D, Villa A, Della Mina P, Menard S, Filipazzi P, Rivoltini L, Tagliabue E and Pupa SM. Potential role of HER2-overexpressing exosomes in countering trastuzumab-based therapy. Journal of cellular physiology. 2012; 227(2):658-667.

171. Mittelbrunn M, Gutierrez-Vazquez C, Villarroya-Beltri C, Gonzalez S, Sanchez-Cabo F, Gonzalez MA, Bernad A and Sanchez-Madrid F. Unidirectional transfer of microRNAloaded exosomes from $\mathrm{T}$ cells to antigen-presenting cells. Nature communications. 2011; 2:282.

172. Longatti A, Boyd B and Chisari FV. Virion-independent transfer of replication-competent hepatitis $\mathrm{C}$ virus RNA between permissive cells. Journal of virology. 2015; 89(5):2956-2961.

173. Lyu L, Wang H, Li B, Qin Q, Qi L, Nagarkatti M, Nagarkatti P, Janicki JS, Wang XL and Cui T. A critical role of cardiac fibroblast-derived exosomes in activating renin angiotensin system in cardiomyocytes. Journal of molecular and cellular cardiology. 2015; 89(Pt B):268-279.

174. Marleau AM, Chen CS, Joyce JA and Tullis RH. Exosome removal as a therapeutic adjuvant in cancer. Journal of translational medicine. 2012; 10:134.

175. Al-Nedawi K, Meehan B, Micallef J, Lhotak V, May L, Guha A and Rak J. Intercellular transfer of the oncogenic receptor EGFRvIII by microvesicles derived from tumour cells. Nature cell biology. 2008; 10(5):619-624.

176. Di Vizio D, Kim J, Hager MH, Morello M, Yang W, Lafargue CJ, True LD, Rubin MA, Adam RM, Beroukhim $\mathrm{R}$, Demichelis $\mathrm{F}$ and Freeman MR. Oncosome formation in prostate cancer: association with a region of frequent chromosomal deletion in metastatic disease. Cancer Res. 2009; 69(13):5601-5609.

177. Antonyak MA, Li B, Boroughs LK, Johnson JL, Druso JE, Bryant KL, Holowka DA and Cerione RA. Cancer cell- 
derived microvesicles induce transformation by transferring tissue transglutaminase and fibronectin to recipient cells. Proceedings of the National Academy of Sciences of the United States of America. 2011; 108(12):4852-4857.

178. Lee TH, Chennakrishnaiah S, Audemard E, Montermini L, Meehan B and Rak J. Oncogenic ras-driven cancer cell vesiculation leads to emission of double-stranded DNA capable of interacting with target cells. Biochem Biophys Res Commun. 2014; 451(2):295-301.

179. Al-Nedawi K, Meehan B, Kerbel RS, Allison AC and Rak J. Endothelial expression of autocrine VEGF upon the uptake of tumor-derived microvesicles containing oncogenic EGFR. Proceedings of the National Academy of Sciences of the United States of America. 2009; 106(10):3794-3799. 